\title{
Impact of harvesting and logging slash on nitrogen and carbon dynamics in soils from upland spruce forests in northeastern Ontario
}

\author{
P.W. Hazlett ${ }^{\mathrm{a}, \mathrm{b}, *}$, A.M. Gordon ${ }^{\mathrm{b}}$, R.P. Voroney ${ }^{\mathrm{c}}$, P.K. Sibley ${ }^{\mathrm{b}}$ \\ ${ }^{a}$ Natural Resources Canada-Canadian Forest Service, 1219 Queen St. E., Sault Ste. Marie, Ont., Canada, P6A 2E5 \\ ${ }^{\mathrm{b}}$ Department of Environmental Biology, University of Guelph, Guelph, Ont., Canada, N1G $2 \mathrm{Wl}$ \\ ${ }^{\mathrm{c}}$ Department of Land Resource Science, University of Guelph, Guelph, Ont., Canada, N1G 2 W1
}

Received 22 January 2006; received in revised form 7 June 2006; accepted 11 June 2006

Available online 28 July 2006

\begin{abstract}
The potential impact of timber harvesting in the boreal forest on aquatic ecosystem water quality and productivity depends in part on the production of nutrients within the soil of the harvested catchment. Nitrogen supplied by organic matter decomposition is of particular interest because of the important role that $\mathrm{N}$ plays in biotic processes in surface waters, and in forest nutrition in general. Logging slash quality and input to the forest floor has the potential to influence $\mathrm{N}$ availability after harvest on clearcut sites. Net production of organic and inorganic- $\mathrm{N}$ and microbial biomass $\mathrm{C}$ and $\mathrm{N}$ concentrations were determined during a 90-day laboratory incubation at constant temperature and moisture. Incubated soils included $\mathrm{F}$ horizon and shallow mineral soil horizons $(0-5 \mathrm{~cm})$ from unharvested and full-tree harvested (2 and 12 growing seasons since harvest) boreal forest sites at the Esker Lakes Research Area (ELRA), in northeastern Ontario, Canada. In an ancillary experiment, black spruce foliage was added to unharvested forest floor material after 30 days during a 90-day laboratory incubation to simulate the influence of logging slash from full-tree harvesting on $\mathrm{C}$ and $\mathrm{N}$ dynamics. Twelve-year old clearcut $\mathrm{F}$ horizon material released on average 75 and 5 times more $\mathrm{NO}_{3}^{-}-\mathrm{N}$ and 3 and 2 times as much inorganic- $\mathrm{N}$ than soil collected from unharvested and 2-year-old clearcuts, respectively. This increase in $\mathrm{NO}_{3}^{-}-\mathrm{N}$ accumulation during the incubation was accompanied by decreases in both exchangeable $\mathrm{NH}_{4}^{+}-\mathrm{N}$ and microbial biomass $\mathrm{C}$ and $\mathrm{N}$ levels. Net daily changes in microbial biomass $\mathrm{N}$ were significantly related to organic and inorganic-N accumulation or loss within the $\mathrm{F}$ horizon. Mineral soil release of inorganic- $\mathrm{N}$ was lower than release from the forest floor. Nitrate-nitrogen accumulation was lower, and $\mathrm{NH}_{4}^{+}-\mathrm{N}$ accumulation was higher in mineral soil from unharvested sites when compared to 12-year-old clearcuts. Calculated harvest response ratios indicated that incubated mineral soil from the 12-year-old clearcut sites released significantly greater amounts of $\mathrm{NO}_{3}^{-}-\mathrm{N}$ than 2-year-old clearcuts. Incorporation of black spruce needles into $\mathrm{F}$ horizon material reduced the production of organic and inorganic- $\mathrm{N}$ and increased microbial biomass $\mathrm{N}$. Laboratory incubations of $\mathrm{F}$ horizon and shallow mineral soil from 12-year-old clearcuts suggested that these boreal soils have the capacity for increased inorganic- $\mathrm{N}$ production compared to uncut stands several years after harvesting. This has the potential to increase $\mathrm{N}$ availability to growing boreal forest plantations and increase $\mathrm{N}$ leaching due to greater $\mathrm{NO}_{3}^{-}-\mathrm{N}$ levels in the forest soil.
\end{abstract}

(C) 2006 Elsevier Ltd. All rights reserved.

Keywords: Boreal forest; Net N mineralization; Immobilization; Logging slash; Microbial biomass; Potential aquatic impacts

\section{Introduction}

Forest harvesting has the potential to increase nutrient inputs to aquatic systems, which can have an eventual impact on surface water quality and biotic response.

\footnotetext{
*Corresponding author. Natural Resources Canada-Canadian Forest Service, 1219 Queen St. E., Sault Ste. Marie, Ont., Canada P6A 2E5. Tel.: + 1705541 5630; fax: + 17055415700 .

E-mail address: phazlett@nrcan.gc.ca (P.W. Hazlett).
}

Increased nitrogen $(\mathrm{N})$ movement from the terrestrial portion of the watershed is of critical importance as it influences productivity and nutrient cycling in aquatic systems (Putz et al., 2003). Whether there will be an increased export of $\mathrm{N}$ after harvesting to aquatic systems depends on the coincident occurrence of increased production and/or decreased uptake by plants and microorganisms within the terrestrial ecosystem and the ability to transfer these nutrients to adjacent receiving waters. The minimal surface water impacts of harvesting reported for 
the Canadian boreal forest region (Nicolson et al., 1982; Carignan et al., 2000; Lamontagne et al., 2000; Steedman 2000; Prepas et al., 2001), even in studies where no shoreline buffer zones had been established, may be partly explained by the limited potential of upland boreal forest soils to mineralize organic- $\mathrm{N}$ to inorganic forms. In general, unharvested boreal forest organic and mineral soils have been shown to have low net inorganic-N production, particularly $\mathrm{NO}_{3}^{-}-\mathrm{N}$. This has been shown in Quebec (Brais et al., 1995; Smith et al., 2000) and Michigan (Stottlemyer and Toczydlowski, 1999) on the boreal shield and in Saskatchewan on the boreal plain (Walley et al., 1996).

Disturbance by forest harvesting causes increases in soil temperature, which, if soil moisture remains adequate, would be expected to increase microbial activity, leading to enhanced organic matter decomposition and increases in inorganic-N production. However, production and immobilization of $\mathrm{N}$ may vary during the time after harvest due to changes in soil organic matter quantity and quality, and microbial activity. Knowledge of the silvicultural plan of a given site (harvest type, site preparation, regeneration approach, vegetation control) and the timing when each component of the plan was executed can assist in the interpretation of changes to substrate characteristics and $\mathrm{N}$ mineralization rates after harvest. In the boreal region of Ontario, large amounts of logging slash are removed from cutovers after harvest and placed in roadside slash piles. These piles are burned, usually during the fall, to clear areas for forest regeneration. In spite of this removal, significant amounts of slash remain on site and this material has the potential to influence $\mathrm{N}$ transformations in cutover soils.

Due to the varied interactions of environmental conditions and composition of substrate, results from several studies in the boreal forest demonstrate that it is not possible to make broad generalizations concerning relationships between clearcut harvesting and net $\mathrm{N}$ mineralization. For example, growing season net forest floor mineralization was greater in 9-year-old full-tree harvested sites when compared to uncut stands in northwestern Quebec (Brais et al., 2002). However, 15 years after harvest the uncut stands in this study had higher net mineralization rates than the harvested sites. Forest harvesting has increased, decreased or resulted in no change to forest floor and mineral soil horizon ammonification and nitrification rates when compared to unharvested boreal stands (Gordon and Van Cleve, 1983; Walley et al., 1996; Smith et al., 1998, 2000; Simard et al., 2001; Carmosini et al., 2002, 2003). The results from these studies agree with the main conclusion of Grenon et al. (2004) in their examination of forest floor $\mathrm{N}$ dynamics in coniferous ecosystems in British Columbia. In their research they recognized responsive and non-responsive sites, and determined that the many factors and mechanisms that control production and consumption of mineral $\mathrm{N}$ will determine the spatiotemporal response of a given $\mathrm{N}$ variable to harvesting. A comprehensive review of soil $\mathrm{N}$ mineralization research by Schimel and Bennett (2004) suggested that research that seeks to provide explanations for differences in terrestrial $\mathrm{N}$ cycling must address the linkages between biotic processes (e.g., depolymerization, mineralization, microbial uptake, root uptake), the role of microsite level dynamics in regulating macroscale $\mathrm{N}$ response, and the contribution of roots and mycorrhizae in creating variable microsites and mediating soil processes.

In this study we assessed $\mathrm{N}$ dynamics in soils from unharvested stands and from two different aged, full-tree harvested sites. We hypothesized that substrate quality, that is the chemical composition of organic residues in the soil, would be modified by silvicultural practices and time since harvest and that this would affect organic matter decomposability and soil $\mathrm{N}$ mineralization. Through the use of standardized incubation conditions we attempted to isolate changes in $\mathrm{N}$ transformation rates due to substrate differences rather than soil physical environment. Our purpose was to determine whether forest harvesting could alter soil $\mathrm{N}$ production, thereby assessing one aspect of the potential susceptibility of boreal aquatic ecosystems to increased $\mathrm{N}$ loading. Our objectives were to determine: (1) the potential rates of soil ammonification, nitrification and net $\mathrm{N}$ mineralization after full-tree harvesting, (2) the influence of logging slash (fresh black spruce needles) on $\mathrm{N}$ transformations in boreal clearcut soils, and (3) relationships between soil microbial biomass and $\mathrm{C}$ and $\mathrm{N}$ dynamics. Specifically, we tested the hypotheses that modifications to substrate quality, resulting from full-tree harvesting, silvicultural practices, clearcut age, and logging slash would influence microbial biomass cycling and $\mathrm{N}$ dynamics.

\section{Materials and methods}

\subsection{Study site description}

The study sites were located at the Esker Lakes Research Area (ELRA) located approximately $75 \mathrm{~km}$ north of Cochrane in northeastern Ontario $\left(49^{\circ} 38^{\prime} \mathrm{N}, 81^{\circ} 00^{\prime} \mathrm{W}\right)$ (Fig. 1). The sites were located on a $15 \mathrm{~km}$ north-south transect along an esker formation that had variable soil textures including up to $40 \%$ clay content in some horizons (Hazlett et al., 2005). The ELRA is located within the Northern Clay Section of the Boreal Forest Region (Rowe, 1972). The soil has a podzolic profile (Soil Classification Working Group, 1998) with a $\mathrm{pH}$ of 4.5 in the forest floor and $>7.0$ at $75 \mathrm{~cm}$ depth in the soil profile. Forest floor horizons stored between 10 and $20 \%$ of the total soil $\mathrm{N}$ to a depth of $75 \mathrm{~cm}$ (Hazlett et al., 2005). The natural forest is typical of undisturbed fire-origin boreal forest, dated at 95 years of age at the time of the study. Dominant tree species include black spruce (Picea mariana (Mill.) BSP), white spruce (Picea glauca (Moench) Voss), balsam fir (Abies balsamea (L.) Mill) and white birch (Betula papyrifera Marsh.). Dominant understory shrub species are mountain maple (Acer spicatum Lamb.), speckled alder (Alnus rugosa 


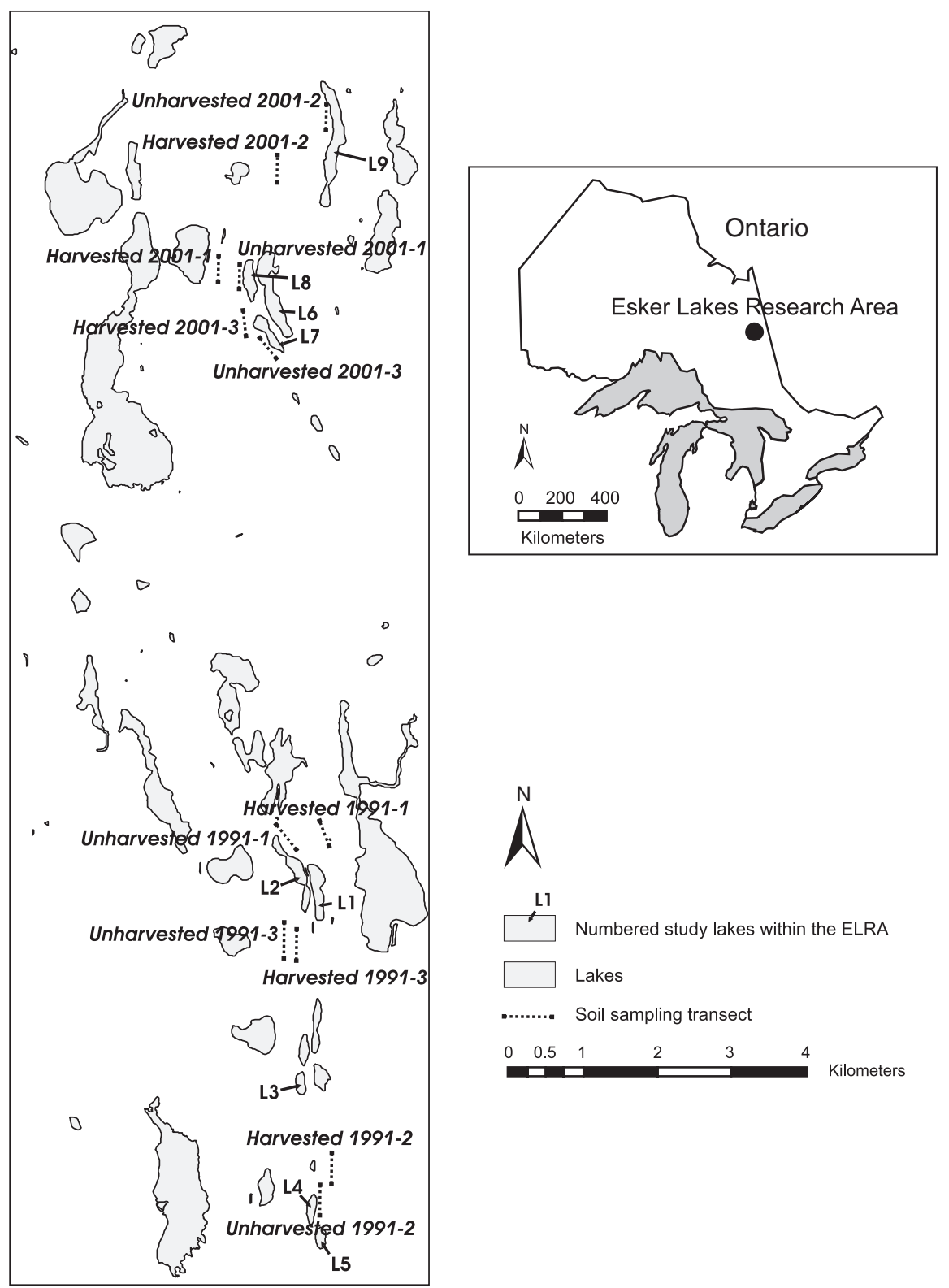

Fig. 1. The Esker Lake Research Area $\left(49^{\circ} 38^{\prime} \mathrm{N}, 81^{\circ} 00^{\prime} \mathrm{W}\right)$ showing study lake and soil sampling transect locations.

(Du Roi) J. Clausen) and beaked hazel (Corylus cornuta Marsh.). The study sites are located within the Albany Climatic Region, within the Arctic watershed with a growing season of 154 days (Chapman and Thomas, 1968). Mean annual temperature and annual precipitation measured at the Environment Canada station at Bonner Lake $\left(49^{\circ} 22^{\prime} \mathrm{N}, 82^{\circ} 07^{\prime} \mathrm{W}\right)$, approximately $80 \mathrm{~km}$ southwest of the ELRA from 1994 to 2003 were $1.6^{\circ} \mathrm{C}$ and $884 \mathrm{~mm}$, respectively, with $36 \%$ of the annual precipitation occurring as snow (Environment Canada, 2004).

\subsection{Experimental design and field sampling}

Three sites that were cut in 1991 and therefore had 12 growing seasons pass since harvest by the time of our study (referred to as Harvested 1991 or 12-year-old clearcuts) were paired with three adjacent uncut stands (referred to as Unharvested 1991), and three sites that were cut in 2001, two growing seasons since harvest, (referred to as Harvested 2001 or 2-year-old clearcuts) were paired with three adjacent uncut stands (referred to as Unharvested 2001). The 1991 and 2001 paired site combinations were located within the southern and northern portions of the study area, respectively. Clearcuts ranged in size from 6 to 12 ha and were full-tree winter harvested using feller-bunchers and skidders. The clearcut areas were planted with black and white spruce in the year immediately after harvest and the 12-year-old clearcuts were aerially herbicided with glyphosate $2-5$ years after plantation establishment. The twelve experimental units were located on upland sites predominantly represented by the black sprucefeathermoss site type, Operational Group 5 in the Ontario Forest Ecosystem Classification System (Jones et al., 1983). 
Samples of $\mathrm{F}$ horizon material and the $0-5 \mathrm{~cm}$ mineral soil layer were sampled at five locations at $25 \mathrm{~m}$ intervals along a $100 \mathrm{~m}$ transect at each clearcut site and paired unharvested stand during June 2003 (Fig. 1). Transects were established so that they were approximately $100 \mathrm{~m}$ from the edge of the clearcut and uncut forest. The mineral soil sample included varying quantities of Ae horizon material and the presence or absence of an Ae was recorded when sampling in the field. Samples of F horizon and mineral soil were composited for each site and frozen at $-20^{\circ} \mathrm{C}$ prior to laboratory processing. Current needle foliage was collected from three overstory black spruce trees at each uncut stand, dried at $70{ }^{\circ} \mathrm{C}$ and bulked into one sample. Logging slash as needle litter was collected from the soil surface at each site harvested in 2001. Three grab samples were bulked into one sample at each site and dried at $70{ }^{\circ} \mathrm{C}$. The mass of 100 black spruce needles was determined for slash and foliage samples.

\subsection{Laboratory incubation and chemical analysis}

In the laboratory, soils were sieved (F horizon, $6 \mathrm{~mm}$; mineral soil, $2 \mathrm{~mm}$ ) to remove roots and rock materials and then homogenized. Field capacity moisture content $(-33 \mathrm{kPa})$ was determined for each sample by pressure plate and then samples were adjusted to this moisture content by air-drying or moisture addition. After the moisture contents were adjusted, subsamples of $\mathrm{F}$ horizon ( $5 \mathrm{~g}$ oven dried equivalent weight) and mineral soil $(20 \mathrm{~g}$ oven dried equivalent weight) were weighed into 40 Dram plastic vials or $120 \mathrm{ml}$ glass vials and stored at $4{ }^{\circ} \mathrm{C}$ for 2 months prior to the beginning of the incubation period. Samples weighed into glass vials were used for the microbial biomass fumigations. Storage was intended to stabilize the impact of soil disturbance and mixing.

Samples were incubated aerobically at $-33 \mathrm{kPa}$ moisture content and $20^{\circ} \mathrm{C}$ with incubation sampling times at 0,7 , 30, 60 and 90 days. The 90-day incubation period was chosen as it was thought that treatment differences would more likely to be discernible in these boreal forest soils after a longer time period than used in many laboratory incubation studies. In addition, the 90-day period represented a reasonable estimate of the time these soils are exposed to elevated soil temperatures in the field. During the incubation, subsamples were held in vials contained in plastic containers $(40 \times 55 \times 15 \mathrm{~cm})$ that were covered with 1.0 mil polyethylene plastic. High humidity and moisture exchange in the soil was maintained by keeping $3 \mathrm{~cm}$ of water depth within the plastic containers and by operating a humidifier within the incubator. Additional subsamples were incubated in $1.5 \mathrm{~L}$ mason jars with a $0.5 \mathrm{M} \mathrm{NaOH}$ trap to determine $\mathrm{CO}_{2}$ evolution. The mason jars were opened weekly to provide aeration for the incubating soil. After 30 days of incubation $1 \mathrm{~g}$ of oven-dried black spruce needle foliage, bulked from all of the unharvested stands, was added to replicate subsamples of $F$ horizon material from the uncut stands. Needles were incorporated into the entire $\mathrm{F}$ horizon sample by gently rolling the incubation vial several times.

At each incubation sampling time, subsamples were removed and extracted with $100 \mathrm{ml}$ of $0.5 \mathrm{M} \mathrm{K}_{2} \mathrm{SO}_{4}$. Microbial biomass $\mathrm{C}\left(\mathrm{C}_{\mathrm{mic}}\right)$ and $\mathrm{N}\left(\mathrm{N}_{\mathrm{mic}}\right)$ were determined on an additional replicate subsample by the fumigationextraction method (Voroney et al., 1993). Samples were shaken for $1 \mathrm{~h}$ followed by filtration by suction for $\mathrm{F}$ horizon samples or by gravity filtration for mineral soil samples. Extract solutions were stored at $-20^{\circ} \mathrm{C}$ prior to analysis. Inorganic- $\mathrm{N}\left(\mathrm{NH}_{4}^{+}-\mathrm{N}\right.$ and $\left.\mathrm{NO}_{3}^{-}-\mathrm{N}\right)$, total $\mathrm{N}$ and dissolved organic carbon were determined by Technicon autoanalyzer IIC using sodium nitroprusside, cadmium reduction, autoclave digestion/cadmium reduction and acid/potassium persulphate methods, respectively. Determination of $\mathrm{CO}_{2}$ was done by titration with standardized $0.25 \mathrm{M} \mathrm{HCl}$ in the presence of phenolphthalein after addition of $3 \mathrm{M} \mathrm{BaCl}_{2}$.

Subsamples of the $\mathrm{F}$ horizon and mineral soil used for the incubation were oven dried at $70^{\circ} \mathrm{C}$ and air dried, respectively, prior to chemical analysis. Organic C and $\mathrm{N}$ concentrations of the soil horizons, foliage and needle litter were determined using a NCS combustion analyzer (Model Vario EL III, Elementar Americas, Inc. Mt. Laurel, NJ, USA) located at the Great Lakes Forestry Centre, Soil Analysis Laboratory in Sault Ste. Marie, Ontario. Analyses of $\mathrm{C}$ and $\mathrm{N}$ are reported on a dry weight basis.

\subsection{Calculations and statistical analysis}

Potential accumulation or depletion of $\mathrm{NO}_{3}^{-}-\mathrm{N}, \mathrm{NH}_{4}^{+}-\mathrm{N}$, total inorganic- $\mathrm{N}$, organic- $\mathrm{N}, \mathrm{C}_{\text {mic }}$ and $\mathrm{N}_{\text {mic }}$ during the incubation were calculated for each time interval and the entire 90-day incubation by subtracting initial from final concentration. To facilitate additional evaluation of the harvest impacts during the incubation while accounting for any heterogeneity of substrate quality across the study area, harvest response ratios for each incubation sampling time were calculated. Using the paired harvested and unharvested stand concentrations,

$$
\begin{aligned}
& \text { Harvest response ratio } \\
& \quad=\ln \left(\frac{\text { harvested stand concentration }}{\text { unharvested stand concentration }}\right) .
\end{aligned}
$$

Initial physical, chemical and biological properties of the incubated soils and the incubation parameters for $F$ horizon and $0-5 \mathrm{~cm}$ mineral soil were analyzed using paired $t$-tests for each clearcut and associated uncut forest combination. The pattern of harvesting from south to north as roads were being constructed into previously unharvested boreal forest did not allow for randomization of the different aged clearcut treatments across the study area. The paired comparison design enabled control for experimental variability in pre-harvest conditions. To facilitate comparisons for incubation parameters between 12-year-old clearcuts and 2-year-old clearcuts, paired 
t-tests were performed on the harvest response ratios calculated by Eq. (1). Residuals were tested for normality with the Shapiro-Wilk test and for homogeneity of variance between treatments and blocks using Bartlett's test. Data that did not meet the test requirements were log transformed. A similar approach was used for the foliage addition experiment using paired $t$-tests between six replications per treatment contrasting unharvested stands to unharvested stands with foliage addition. Relationships between the incubation response variables and soil biological and chemical properties were determined using correlation and regression. Statistical analyses were performed using the GLM, COR and REG procedures and the LSMEANS statement in SAS Version 8.2 (SAS Institute, Cary, NC, USA). Results were considered statistically significant at $\alpha<0.05$.

\section{Results}

\subsection{Chemical and biological properties of incubated soils}

Although $\mathrm{F}$ horizon material sampled from 12-year-old clearcuts had higher $\mathrm{N}$ and lower $\mathrm{C}$ concentrations, and lower $\mathrm{C}: \mathrm{N}$ ratios than paired unharvested sites, these differences were not statistically significant (Table 1).
Shallow mineral soils sampled from harvested sites had C and $\mathrm{N}$ concentrations that were not significantly different from associated unharvested stands (Table 2). There was no significant effect of harvesting on the initial $\mathrm{C}_{\text {mic }}$ and $\mathrm{N}_{\text {mic }}$ levels or on the contribution of $\mathrm{C}_{\text {mic }}$ to total soil $\mathrm{C}$ $\left(\mathrm{C}_{\text {mic }}: \mathrm{C}\right)$ and the contribution of $\mathrm{N}_{\text {mic }}$ to total soil $\mathrm{N}$ $\left(\mathrm{N}_{\text {mic }}: \mathrm{N}\right)$ for either the $\mathrm{F}$ horizon (Table 1) or the mineral soil (Table 2). In spite of the absence of statistically significant differences, the recently harvested site had the lowest mean values of $\mathrm{C}_{\text {mic }}, \mathrm{N}_{\text {mic }}, \mathrm{C}_{\text {mic }}: \mathrm{C}$ and $\mathrm{N}_{\text {mic }}: \mathrm{N}$ for both organic and mineral horizons. The mean microbial biomass $\mathrm{C}$ to microbial biomass $\mathrm{N}$ ratio $\left(\mathrm{C}_{\text {mic }}: \mathrm{N}_{\text {mic }}\right)$ across all sites for both soil layers ranged from 3.8 to 4.8 .

\subsection{Harvesting impacts}

The laboratory incubation results are presented as total net accumulation or loss of inorganic and organic-N, $\mathrm{C}_{\text {mic }}$ and $\mathrm{N}_{\text {mic }}$ over the 90 -day incubation period (Table 3). In addition, the patterns of accumulation and loss over the 90 days of incubation for the same response variables and $\mathrm{CO}_{2}-\mathrm{C}$ evolution are shown in Figs. 2-5.

Ammonium accumulation for the $\mathrm{F}$ horizon of the unharvested sites increased slowly during the incubation period and nitrification was absent or very low (Fig. 2),

Table 1

Physical, chemical and biological properties of F horizon sampled from unharvested and harvested sites at the ELRA and used for laboratory incubation experiments (means with SE in parentheses for three blocks for each site type - each block was sampled at five locations on a $100 \mathrm{~m}$ transect)

\begin{tabular}{|c|c|c|c|c|c|c|c|c|c|c|}
\hline & $\begin{array}{l}\text { Depth } \\
(\mathrm{cm})\end{array}$ & $\begin{array}{l}-33 \mathrm{kPa} \\
\mathrm{MC}(\%)\end{array}$ & $\begin{array}{l}\mathrm{C} \\
\left(\mathrm{g} \mathrm{kg}^{-1}\right)\end{array}$ & $\begin{array}{l}\mathrm{N} \\
\left(\mathrm{g} \mathrm{kg}^{-1}\right)\end{array}$ & $\mathrm{C}: \mathrm{N}$ & $\begin{array}{l}\mathrm{C}_{\text {mic }} \\
\left(\mu \mathrm{g} \mathrm{g}^{-1}\right)\end{array}$ & $\begin{array}{l}\mathrm{N}_{\text {mic }} \\
\left(\mu \mathrm{g} \mathrm{g}^{-1}\right)\end{array}$ & $\begin{array}{l}\mathrm{C}_{\text {mic }}: \mathrm{C} \\
(\%)\end{array}$ & $\begin{array}{l}\mathrm{N}_{\text {mic }}: \mathrm{N} \\
(\%)\end{array}$ & $\mathrm{C}_{\text {mic }}: \mathrm{N}_{\text {mic }}$ \\
\hline $\begin{array}{l}\text { Harvested } \\
1991\end{array}$ & $2.4(0.2)$ & $189.3(9.4)$ & $413(7)$ & 23.7 (1.4) & $17.5(0.8)$ & $12,149(1535)$ & $3101(525)$ & $3.0(0.4)$ & $13.4(3.0)$ & $4.0(0.2)$ \\
\hline $\begin{array}{l}\text { Unharvested } \\
1991\end{array}$ & $4.1(0.8)$ & $182.7(5.0)$ & $443(11)$ & $18.2(2.5)$ & $25.2(3.3)$ & $12,740(2663)$ & $3562(1155)$ & $2.9(0.6)$ & $18.8(3.7)$ & $3.8(0.4)$ \\
\hline $\begin{array}{l}\text { Harvested } \\
2001\end{array}$ & $7.2(0.6)$ & $202.0(6.6)$ & $440(7)$ & $19.2(0.9)$ & $23.0(1.3)$ & 9393 (697) & 2268 (224) & $2.1(0.1)$ & $11.8(1.1)$ & $4.2(0.1)$ \\
\hline $\begin{array}{l}\text { Unharvested } \\
2001\end{array}$ & $7.4(1.5)$ & $197.4(5.7)$ & 449 (4) & $17.5(1.7)$ & $26.2(2.6)$ & $11,461(2321)$ & 2798 (696) & $2.5(0.5)$ & $15.5(2.7)$ & $4.2(0.3)$ \\
\hline
\end{tabular}

Paired $t$-tests for each harvested-unharvested means combination (1991 or 2001) are not significantly different at $p<0.05$.

Table 2

Physical, chemical and biological properties of mineral soil $(0-5 \mathrm{~cm}$ depth) sampled from unharvested and harvested sites at the ELRA and used for laboratory incubation experiments (means with SE in parentheses for three blocks for each site type - each block was sampled at five locations on a $100 \mathrm{~m}$ transect)

\begin{tabular}{|c|c|c|c|c|c|c|c|c|c|c|}
\hline & $\begin{array}{l}\text { Frequency } \\
\text { of Ae }(\%)\end{array}$ & $\begin{array}{l}-33 \mathrm{kPa} \\
\mathrm{MC}(\%)\end{array}$ & $\begin{array}{l}\mathrm{C} \\
\left(\mathrm{g} \mathrm{kg}^{-1}\right)\end{array}$ & $\begin{array}{l}\mathrm{N} \\
\left(\mathrm{g} \mathrm{kg}^{-1}\right)\end{array}$ & $\mathrm{C}: \mathrm{N}$ & $\begin{array}{l}\mathrm{C}_{\mathrm{mic}} \\
\left(\mu \mathrm{gg}^{-1}\right)\end{array}$ & $\begin{array}{l}\mathrm{N}_{\text {mic }} \\
\left(\mu \mathrm{gg}^{-1}\right)\end{array}$ & $\begin{array}{l}\mathrm{C}_{\mathrm{mic}}: \mathrm{C} \\
(\%)\end{array}$ & $\begin{array}{l}\mathrm{N}_{\text {mic }}: \mathrm{N} \\
(\%)\end{array}$ & $\mathrm{C}_{\mathrm{mic}}: \mathrm{N}_{\mathrm{mic}}$ \\
\hline $\begin{array}{l}\text { Harvested } \\
1991\end{array}$ & $40(12)$ & $24.9(1.9)$ & $14.6(2.6)$ & $1.2(0.2)$ & $12.1(0.3)$ & $454(143)$ & 117 (35) & $3.1(0.7)$ & $9.7(2.2)$ & $3.8(0.1)$ \\
\hline $\begin{array}{l}\text { Unharvested } \\
1991\end{array}$ & $80(0)$ & $21.4(3.3)$ & $10.2(1.6)$ & $0.7(0.2)$ & $15.7(1.8)$ & $323(64)$ & 77 (16) & $3.2(0.5)$ & $12.0(2.7)$ & $4.3(0.3)$ \\
\hline $\begin{array}{l}\text { Harvested } \\
2001\end{array}$ & $67(18)$ & $29.6(0.6)$ & $14.9(1.4)$ & $1.1(0.1)$ & $13.4(0.2)$ & $263(50)$ & $72(20)$ & $1.8(0.3)$ & $6.3(1.3)$ & $4.0(1.0)$ \\
\hline $\begin{array}{l}\text { Unharvested } \\
2001\end{array}$ & $73(18)$ & $29.7(3.4)$ & $18.7(4.6)$ & $1.2(0.2)$ & $15.2(1.4)$ & $437(70)$ & $92(17)$ & $2.6(0.7)$ & $8.4(2.6)$ & $4.8(0.7)$ \\
\hline
\end{tabular}

Paired $t$-tests for each harvested-unharvested means combination (1991 or 2001) are not significantly different at $p<0.05$. Frequency of Ae indicates the percentage of sampling points on each sampling transect with Ae horizon present. 
Table 3

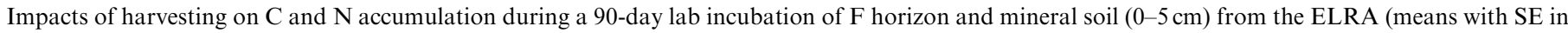
parentheses for 3 blocks for each site type - each block was sampled at five locations on a $100 \mathrm{~m}$ transect)

\begin{tabular}{|c|c|c|c|c|c|c|c|}
\hline & \multicolumn{4}{|c|}{ Treatment means } & \multirow{2}{*}{$\begin{array}{l}\text { U91 vs H91 } \\
p\end{array}$} & \multirow{2}{*}{$\begin{array}{l}\mathrm{U} 01 \text { vs } \mathrm{H} 01 \\
p\end{array}$} & \multirow{2}{*}{$\begin{array}{l}\text { HRR91 vs HRR0 }^{\mathrm{b}} \\
p\end{array}$} \\
\hline & U91 & H91 & U01 & H01 & & & \\
\hline \multicolumn{8}{|l|}{$F$ horizon } \\
\hline $\mathrm{NO}_{3}^{-}-\mathrm{N}\left(\mu \mathrm{gg}^{-1}\right)^{\mathrm{a}}$ & $16(4)$ & $1220(267)$ & $13(1)$ & $257(171)$ & 0.011 & 0.457 & 0.307 \\
\hline $\mathrm{NH}_{4}^{+}-\mathrm{N}\left(\mu \mathrm{gg}^{-1}\right)$ & $424(214)$ & $-80(85)$ & $289(157)$ & $305(118)$ & 0.125 & 0.442 & 0.214 \\
\hline Inorganic- $N\left(\mu \mathrm{gg}^{-1}\right)$ & $440(218)$ & $1140(203)$ & $303(157)$ & $562(137)$ & 0.234 & 0.689 & 0.297 \\
\hline Organic-N $\left(\mu \mathrm{gg}^{-1}\right)$ & $51(28)$ & $215(52)$ & $100(1)$ & $85(40)$ & 0.165 & 0.798 & 0.125 \\
\hline $\mathrm{C}_{\mathrm{mic}}\left(\mu \mathrm{gg}^{-1}\right)$ & $226(1292)$ & $-10006(1854)$ & $-1187(635)$ & $-2652(1289)$ & 0.005 & 0.440 & 0.668 \\
\hline $\mathrm{N}_{\text {mic }}\left(\mu \mathrm{g} \mathrm{g}^{-1}\right)$ & $-342(523)$ & $-2348(219)$ & $-207(52)$ & $-855(399)$ & 0.111 & 0.618 & 0.705 \\
\hline \multicolumn{8}{|l|}{ Mineral soil $0-5 \mathrm{~cm}$} \\
\hline $\mathrm{NO}_{3}^{-}-\mathrm{N}\left(\mu \mathrm{gg}^{-1}\right)^{\mathrm{a}}$ & $2(1)$ & $41(11)$ & $4(3)$ & $21(3)$ & 0.038 & 0.037 & 0.030 \\
\hline $\mathrm{NH}_{4}^{+}-\mathrm{N}\left(\mu \mathrm{gg}^{-1}\right)$ & $14(4)$ & $-5(1)$ & $12(1)$ & $4(2)$ & 0.029 & 0.053 & 0.069 \\
\hline Inorganic- $N\left(\mu \mathrm{gg}^{-1}\right)$ & $16(5)$ & $36(10)$ & $16(3)$ & $26(1)$ & 0.299 & 0.068 & 0.325 \\
\hline Organic- $N\left(\mu \mathrm{g} \mathrm{g}^{-1}\right)$ & $7(1)$ & $4(2)$ & $5(3)$ & $7(1)$ & 0.232 & 0.599 & 0.307 \\
\hline $\mathrm{C}_{\mathrm{mic}}\left(\mu \mathrm{gg}^{-1}\right)$ & $-28(28)$ & $-123(9)$ & $-135(104)$ & $-16(39)$ & 0.083 & 0.304 & 0.556 \\
\hline $\mathrm{N}_{\text {mic }}\left(\mu \mathrm{gg}^{-1}\right)$ & $-9(15)$ & $-48(27)$ & $-20(18)$ & $-4(17)$ & 0.277 & 0.645 & 0.454 \\
\hline
\end{tabular}

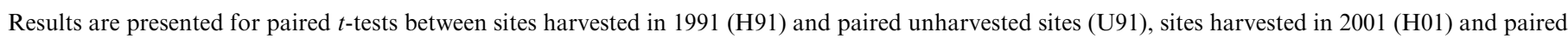
unharvested sites (U01) and harvest response ratios from 1991 (HRR91) and 2001 (HRR01). Bolded values indicate significance at $p<0.05$.

${ }^{\text {a }}$ Data log transformed.

${ }^{\mathrm{b}}$ Harvest response ratio $=\ln$ (harvested stand concentration/unharvested stand concentration).

while the harvested sites had increased nitrification trends with significant 90-day accumulations for 12-year-old clearcuts compared to associated unharvested sites (Table 3). Sites harvested in 1991 produced, on average, five times as much $\mathrm{NO}_{3}^{-}-\mathrm{N}$ during the incubation period as the sites harvested in 2001. Increased $\mathrm{NO}_{3}^{-}-\mathrm{N}$ production in $\mathrm{F}$ horizon material from the old clearcuts was associated with low $\mathrm{NH}_{4}^{+}-\mathrm{N}$ concentrations (Fig. 2), and decreasing $\mathrm{C}_{\text {mic }}$, $\mathrm{N}_{\text {mic }}$ and $\mathrm{CO}_{2}-\mathrm{C}$ evolution over the 90 days of incubation (Fig. 3). These $\mathrm{F}$ horizons had a net loss of $\mathrm{NH}_{4}^{+}-\mathrm{N}$ over the incubation period in contrast to the net accumulation at 2-year-old clearcuts and unharvested sites (Table 3). The net 90-day incubation loss of $\mathrm{C}_{\text {mic }}$ from the 1991 clearcuts was statistically greater than the slight accumulation for 1991 unharvested sites (Table 3). Mean organic-N concentrations were greater in old clearcut $\mathrm{F}$ horizons when compared to recent clearcuts and unharvested sites; however, net accumulation was not significantly different over the 90-day incubation (Table 3). Organic-N concentrations in incubated $\mathrm{F}$ horizons from all sites constituted, on average, approximately $15 \%$ of the total $\mathrm{N}$ present. However, for the clearcuts harvested in 1991, organic-N concentrations were greater than $\mathrm{NH}_{4}^{+}-\mathrm{N}$ concentrations throughout the incubation. The patterns in $\mathrm{C}_{\text {mic }}, \mathrm{N}_{\text {mic }}$ and $\mathrm{CO}_{2}-\mathrm{C}$ evolution during the $\mathrm{F}$ horizon incubation were similar for the 2-year-old clearcuts and unharvested sites (Fig. 3). There was no significant difference between the net loss of $\mathrm{C}_{\text {mic }}$ and $\mathrm{N}_{\text {mic }}$ for the recent clearcuts and associated uncut stands over the entire 90-day incubation (Table 3).

Mineral soil sampled from the unharvested sites had incubation concentrations of $\mathrm{NO}_{3}^{-}-\mathrm{N}$ and $\mathrm{NH}_{4}^{+}-\mathrm{N}$ much lower than the $\mathrm{F}$ horizon but patterns of accumulation over the 90-day incubation were similar for both the organic and mineral layers used in this study (Table 3, Figs. 2 and 4). Organic-N constituted a larger portion of the total extractable $\mathrm{N}$ in mineral soils from the unharvested sites relative to the $\mathrm{F}$ horizon, and nitrification was limited (Fig. 4). The concentration of $\mathrm{NH}_{4}^{+}-\mathrm{N}$ for harvested mineral soils initially increased during the incubation, but declined after 30 days for the old clearcuts, and stayed at the same level for days 30-90 for recent clearcuts. The net loss of $\mathrm{NH}_{4}^{+}-\mathrm{N}$ during the 90-day incubation for the sites harvested in 1991 was significantly different from the net accumulation for 1991 unharvested sites (Table 3). Nitrate concentrations constantly increased for mineral soils from clearcut treatments during the incubation period (Fig. 4), and total $\mathrm{NO}_{3}^{-}-\mathrm{N}$ accumulation for the 90-days for 12year-old and 2-year-old cutovers was significantly greater than the accumulation at paired unharvested sites (Table 3). Organic-N levels for the unharvested stands and recently harvested clearcuts were comparable, and contributed approximately $25 \%$ to the total $\mathrm{N}$ concentration of the mineral soils. For the 12-year-old clearcuts, total organic-N concentrations changed very little during the incubation, however increasing nitrification rates later in the incubation led to a smaller proportion of the total $\mathrm{N}$ concentration being attributed to organic-N (Fig. 4). Mineral soils from all sites had a net loss of $\mathrm{C}_{\text {mic }}$ and $\mathrm{N}_{\text {mic }}$ during the laboratory incubation, but losses from clearcut sites were not significantly different from their associated uncut stands (Table 3). In the case of $\mathrm{C}_{\text {mic }}$ there was a rapid decrease in biomass levels during the early stages of the incubation followed by a steady increase to 90 days, with final concentrations still below initial levels (Fig. 5). 

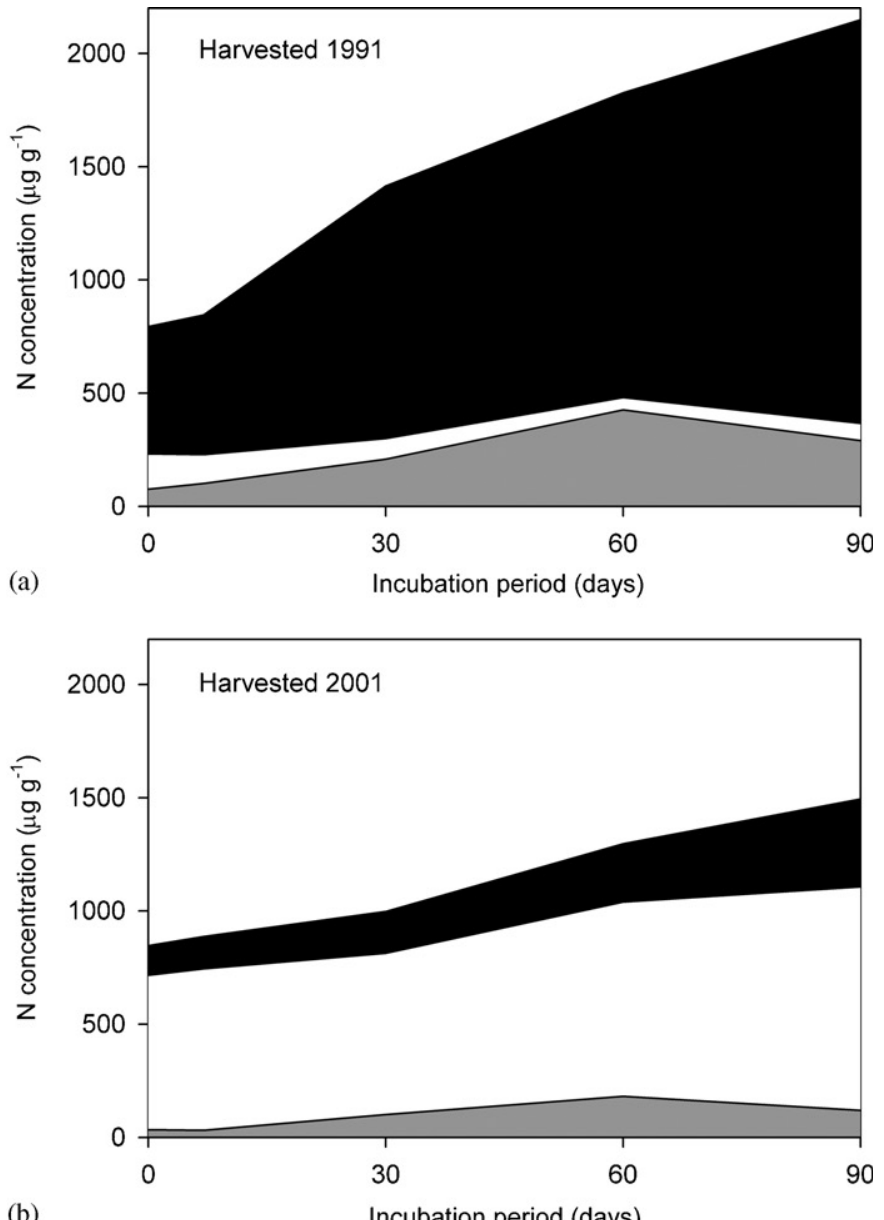

(b)

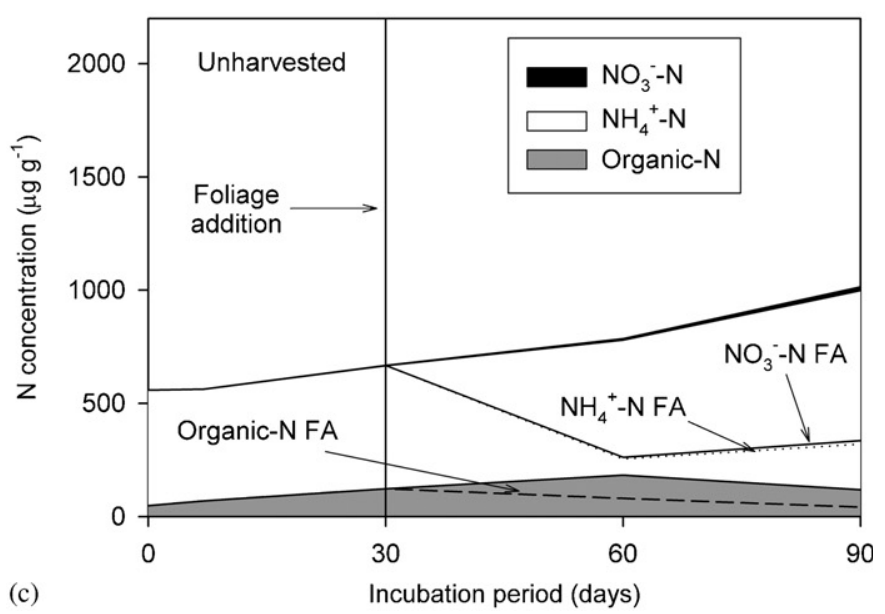

Fig. 2. Patterns of accumulation or loss of inorganic $\left(\mathrm{NO}_{3}^{-}-\mathrm{N}\right.$ and $\mathrm{NH}_{4}^{+}-$ $\mathrm{N})$ and organic- $\mathrm{N}$ during a 90-day laboratory incubation of $\mathrm{F}$ horizon from (a) harvested 1991 (b) harvested 2001 and (c) unharvested sites at the Esker Lake Research Area. Unharvested figure also shows foliage addition (FA) treatment.

However, only for the 12-year-old clearcut was the 90 day $\mathrm{C}_{\text {mic }}$ concentration significantly less than that at time 0 for the incubation $(p=.005)$. The trend for $\mathrm{C}_{\text {mic }}$, was matched by increased $\mathrm{CO}_{2}-\mathrm{C}$ evolution from 30 to 60 day incubation for the harvested sites; however, $\mathrm{CO}_{2}-\mathrm{C}$ evolution rates declined from 60 to 90 days during the incubation.

\subsection{Foliage addition}

Black spruce foliage added to unharvested $\mathrm{F}$ horizon material at day 30 of the incubation resulted in a sharp decline in $\mathrm{NH}_{4}^{+}-\mathrm{N}$ concentrations to day 60 (Fig. 2). The net loss of $\mathrm{NH}_{4}^{+}-\mathrm{N}$ from day 30-90 was significantly different from the net accumulation for unharvested sites without foliage addition and led to a significant net loss in inorganic- $\mathrm{N}$ over the 60 days of the incubation (Table 4). This was accompanied by a doubling of $\mathrm{CO}_{2}-\mathrm{C}$ production in comparison with the unamended $\mathrm{F}$ horizon and increases in $\mathrm{C}_{\text {mic }}$ and $\mathrm{N}_{\text {mic }}$ (Fig. 3). Organic-N concentrations after foliage addition were lower than for unamended F horizon material; however, the net loss over the 60-day incubation between the two was not significantly different.

\section{4. $N$ mineralization, microbial biomass and soil $C$ and $N$}

Using the daily accumulation or loss for the 0-90 day time period for the harvested and unharvested sites we assessed the relationships between initial soil $\mathrm{C}$ and $\mathrm{N}$ and net inorganic and organic- $\mathrm{N}$ production (Table 5). The influence of changes in $\mathrm{C}_{\text {mic }}$ and $\mathrm{N}_{\text {mic }}$ during incubation on $\mathrm{N}$ mineralization of the $\mathrm{F}$ horizon was examined using the 90 day incubation and also the 30-90 day time period for the foliage addition experiment (Fig. 6). We were able to assess the influence of microbial biomass $\mathrm{N}$ over a broad range of net daily change because of the inclusion of the foliage addition experiment in our analysis. In general, unharvested and harvested sites had net daily changes in $\mathrm{C}_{\text {mic }}$ and $\mathrm{N}_{\text {mic }}$ during the incubation that were negative, while the $\mathrm{F}$ horizons amended with foliage produced a positive net change. Inorganic- $\mathrm{N}$ and $\mathrm{NO}_{3}^{-}-\mathrm{N}$ production rates in the $\mathrm{F}$ horizon were significantly related to soil $\mathrm{N}$ (positively) and soil $\mathrm{C}$ and $\mathrm{C}: \mathrm{N}$ (negatively) (Table 5). There were no significant relationships between soil $\mathrm{C}$ and $\mathrm{N}$ and net rates of $\mathrm{N}$ mineralization in the mineral soil from our sites (Hazlett, unpublished data). There were significant negative linear regressions between net change in $\mathrm{NH}_{4}^{+}-\mathrm{N}$, inorganic$\mathrm{N}$ and organic- $\mathrm{N}$ and net change in $\mathrm{N}_{\text {mic }}$. Net losses of forms of $\mathrm{N}$ during the incubation occurred predominantly when the net change in $\mathrm{N}_{\text {mic }}$ was greater than zero. The best fit for the $\mathrm{NO}_{3}^{-}-\mathrm{N}$ relationship with $\mathrm{N}_{\text {mic }}$ was an exponential decay function that indicated a net change threshold of $\mathrm{N}_{\text {mic }}$ between -10 and $-20 \mu \mathrm{gg}^{-1} \mathrm{day}^{-1}$ before any nitrification occurred within the $\mathrm{F}$ horizons sampled. Net change in $\mathrm{C}_{\text {mic }}$ for the $\mathrm{F}$ horizon was significantly related only to net change in inorganic- $\mathrm{N}(p=0.013)$. Mineral soil $\mathrm{N}$ production during the incubation was not correlated with changes in mineral soil $\mathrm{C}_{\text {mic }}$ and $\mathrm{N}_{\text {mic }}$ (Hazlett, unpublished data).

\section{Discussion}

\subsection{Harvesting impacts and logging slash}

Levels of inorganic- $\mathrm{N}$ accumulation for the $\mathrm{F}$ horizon of unharvested stands at the ELRA were somewhat greater 


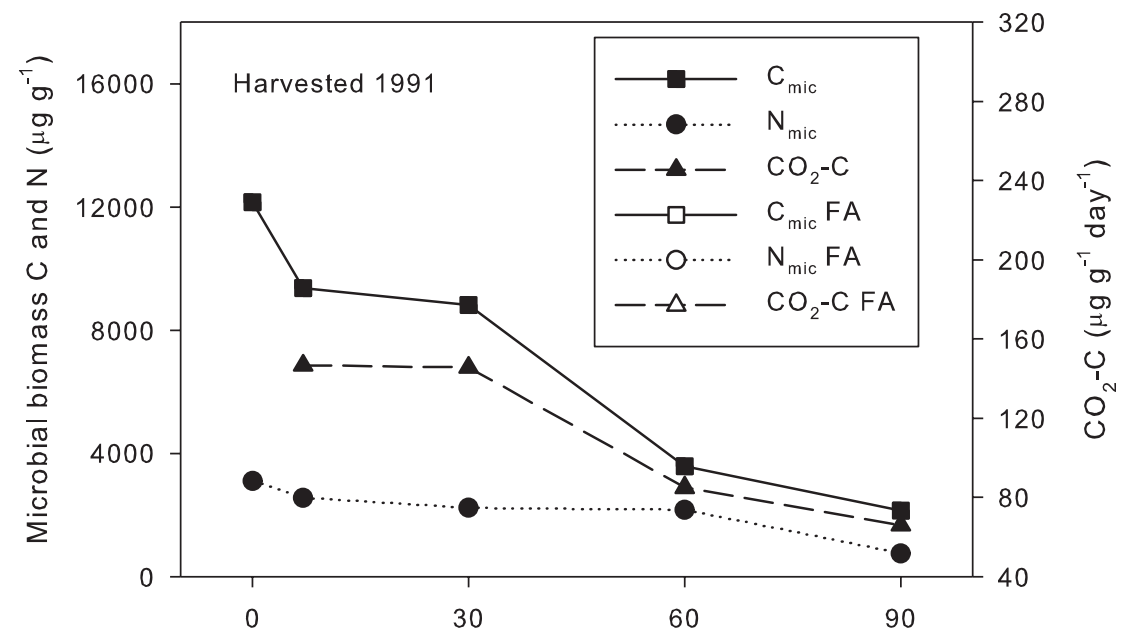

(a)

Incubation period (days)

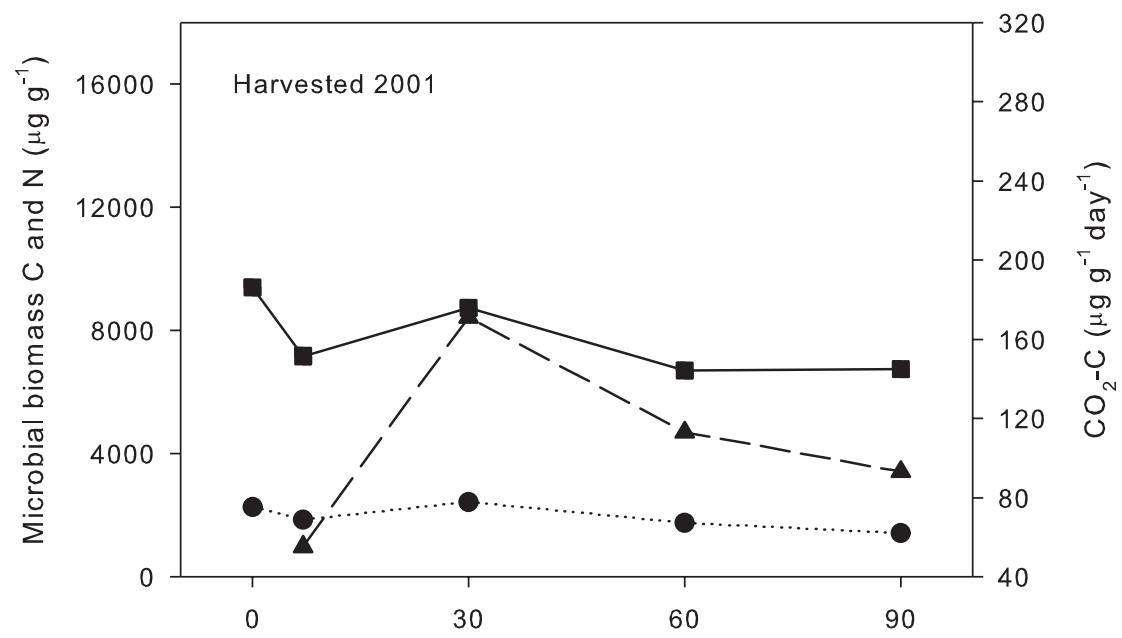

(b)

Incubation period (days)

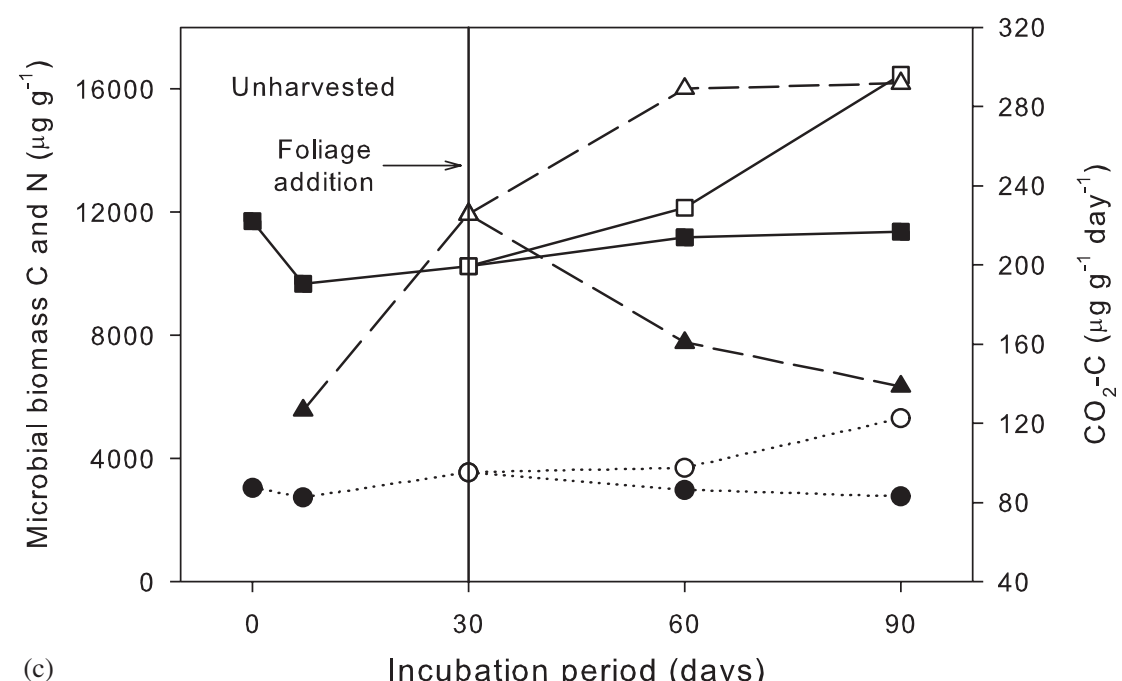

Fig. 3. Patterns of accumulation or loss of microbial biomass $\mathrm{C}\left(\mathrm{C}_{\mathrm{mic}}\right)$ and $\mathrm{N}\left(\mathrm{N}_{\text {mic }}\right)$, and $\mathrm{CO}_{2}-\mathrm{C}$ evolution during a 90 -day laboratory incubation of $\mathrm{F}$ horizon from (a) harvested 1991 (b) harvested 2001 and (c) unharvested sites at the Esker Lake Research Area. Unharvested figure also shows foliage addition (FA) treatment. 

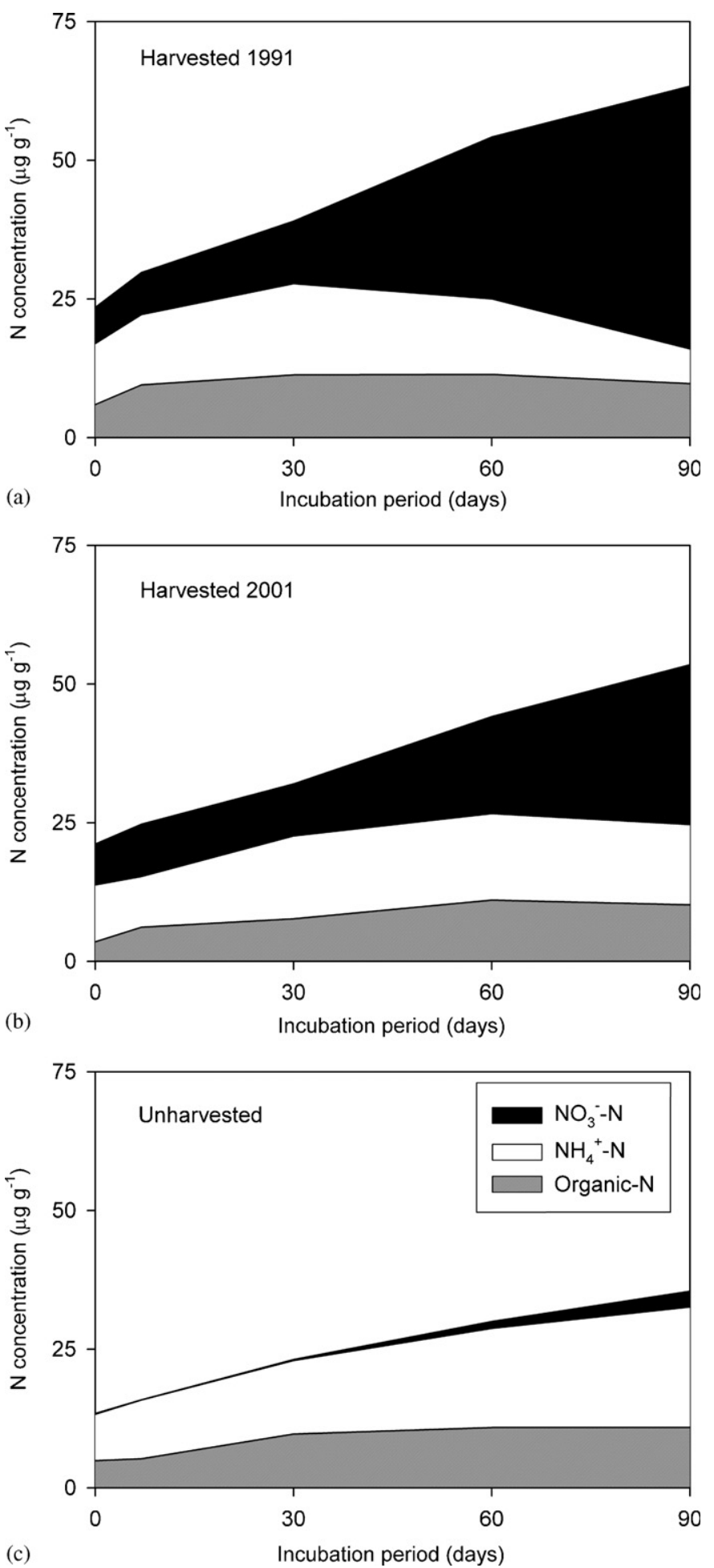

(c)

Fig. 4. Patterns of accumulation or loss of inorganic $\left(\mathrm{NO}_{3}^{-}-\mathrm{N}\right.$ and $\mathrm{NH}_{4}^{+}$$\mathrm{N}$ ) and organic-N during a 90-day laboratory incubation of mineral soil 0 $5 \mathrm{~cm}$ depth from (a) harvested 1991 (b) harvested 2001 and (c) unharvested sites at the Esker Lake Research Area.

than those reported for the organic layers from black spruce stands in the Quebec boreal forest (Simard et al., 2001). While sample preparation was similar and the temperature and moisture conditions comparable the length of our incubation period was twice that used in the Quebec study. The low levels of net nitrification for $\mathrm{F}$ horizon and surface mineral soils from our unharvested sites relative to other forest types have been consistently reported for laboratory and field incubations of soils from black spruce forests (Paré and Bergeron, 1996; Smith et al., 1998; Simard et al., 2001). Low levels of net mineralization and the absence of nitrification has been most often attributed to the poor nutrient quality of coniferous litter (low $\mathrm{N}$ and high $\mathrm{C}: \mathrm{N}$ ratio).

We had hypothesized that the addition of organic matter from logging slash to unharvested $\mathrm{F}$ horizon material would increase $\mathrm{N}$ immobilization within the microbial biomass and limit inorganic-N production. Our results show significant decreases in net ammonification and net mineralization, and significant increases in $\mathrm{N}_{\text {mic }}$ over the 60-day incubation period when contrasting $\mathrm{F}$ horizon amended with black spruce foliage to soil without foliage addition. We observed needle color change from green to yellow and physical deterioration along the edges of the needles incorporated in the $\mathrm{F}$ horizon two weeks after addition to the soil. The increase in $\mathrm{C}_{\text {mic }}$ and $\mathrm{N}_{\text {mic }}$ seemed to indicate that microorganisms within the black spruce $\mathrm{F}$ horizon were able to utilize labile $\mathrm{C}$ contained in the added foliage. As a result, microbial activity increased, as evidenced by a significant flush in $\mathrm{CO}_{2}-\mathrm{C}$ evolution. While stimulation of microbial biomass by foliage addition significantly decreased the concentrations of exchangeable $\mathrm{NH}_{4}^{+}-\mathrm{N}$ in incubated samples from 30 to 60 days $(p=0.035)$, this decrease did not continue from 60 to 90 days. In spite of the continued slight increase in $\mathrm{N}_{\text {mic }}$ during the latter 30 days of the incubation for foliage amended samples $(p=0.061)$, the increase in $\mathrm{NH}_{4}^{+}-\mathrm{N}$ concentration indicated that net accumulation rather than immobilization of $\mathrm{NH}_{4}^{+}-\mathrm{N}$ was occurring during this period. During the 60-90 day period of the incubation gross ammonification rates were exceeding gross consumption rates, resulting in $\mathrm{NH}_{4}^{+}-\mathrm{N}$ accumulation. Foliage addition had no impact on $\mathrm{NO}_{3}^{-}-\mathrm{N}$ levels, which maintained net rates comparable to the unamended $\mathrm{F}$ horizon during the 60 day incubation. The reduction in inorganic- $\mathrm{N}$ concentrations in forest soils after the addition of a $\mathrm{C}$ supply has been demonstrated in previous studies. Bååth et al. (1978) used a microcosm experiment to demonstrate that $\mathrm{C}$ additions as glucose to humus from Scots pine stands resulted in retention of $\mathrm{N}$ by soil organisms, and as a result, poor growth of tree seedlings. In a 12-week laboratory incubation, Pluth et al. (1995) reported that the incorporation of Scots pine residues into the surface $0-10 \mathrm{~cm}$ of a peat soil resulted in a depressed accumulation of inorganic-N caused by increased net microbial immobilization. The results of the foliage addition laboratory incubation suggested that the decomposition of slash from full-tree harvesting could initially result in microbial immobilization of $\mathrm{N}$ within the $\mathrm{F}$ horizon of boreal clearcuts.

Incubation results for organic and mineral soils from 2-year-old clearcuts showed increased nitrification compared to unharvested stands, although the differences were 


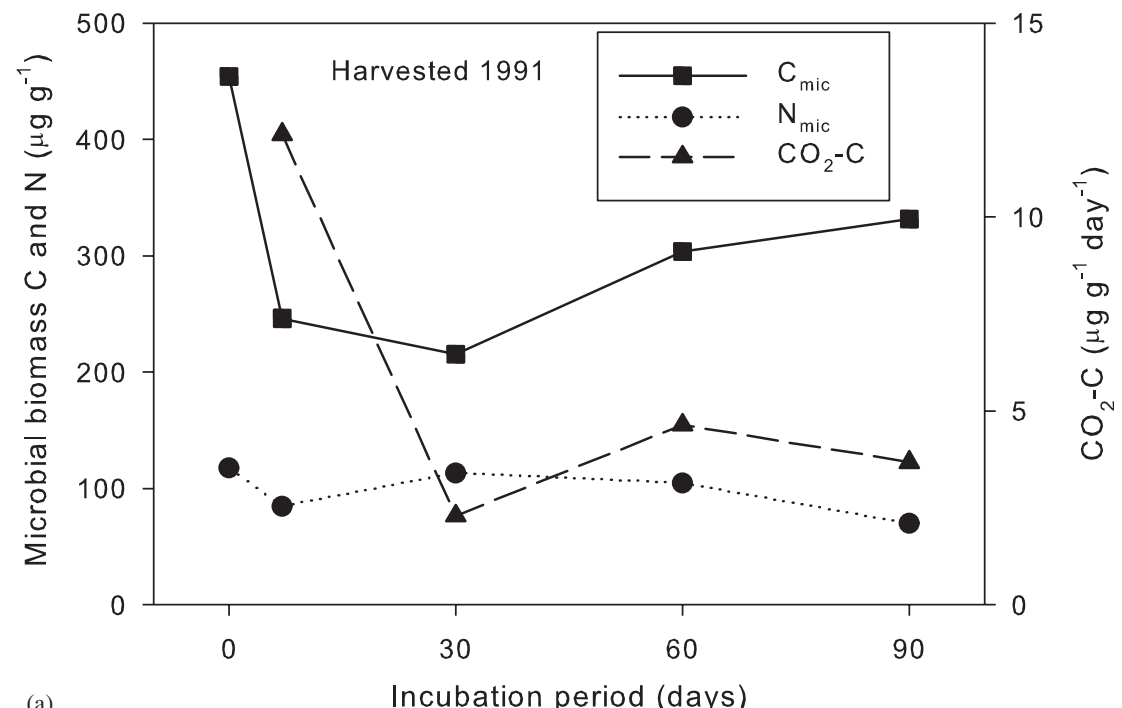

(a)

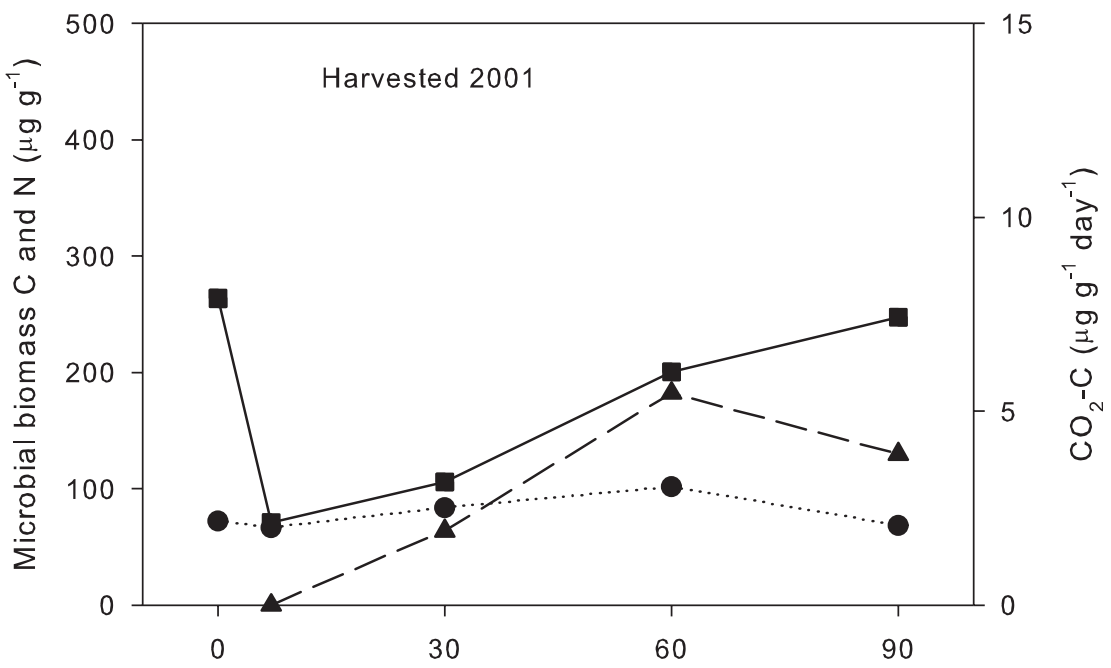

(b)

Incubation period (days)

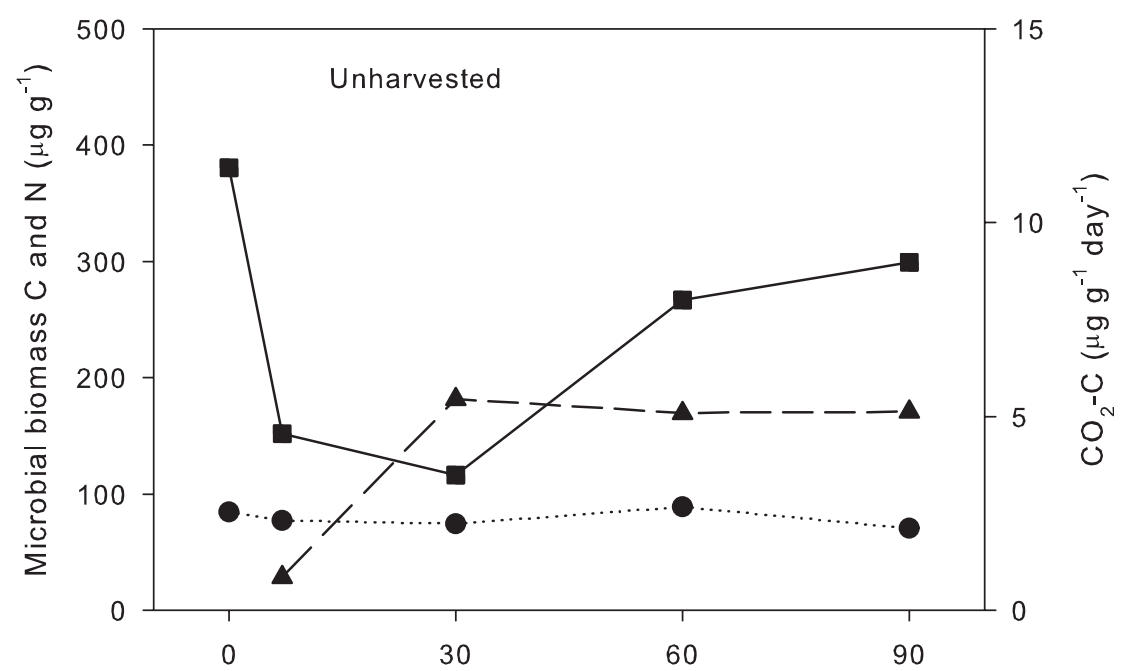

(c)

Incubation period (days)

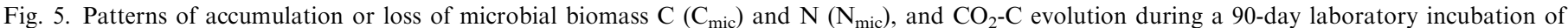
mineral soil 0-5 cm from (a) harvested 1991 (b) harvested 2001 and (c) unharvested sites at the Esker Lake Research Area. 
Table 4

Impacts of harvesting on $\mathrm{C}$ and $\mathrm{N}$ accumulation during a 60-day lab incubation of $\mathrm{F}$ horizon with foliage addition from the ELRA (means with SE in parentheses for six blocks for each treatment - each block was sampled at five locations on a $100 \mathrm{~m}$ transect)

\begin{tabular}{|c|c|c|c|}
\hline & \multicolumn{2}{|c|}{ Treatment means } & \multirow{2}{*}{$\begin{array}{l}\mathrm{U} \text { vs UFA } \\
p\end{array}$} \\
\hline & Unharvested & Unharvested foliage addition & \\
\hline $\mathrm{NO}_{3}^{-}-\mathrm{N}\left(\mu \mathrm{gg}^{-1}\right)^{\mathrm{a}}$ & $14(2)$ & $15(8)$ & 0.331 \\
\hline $\mathrm{NH}_{4}^{+}-\mathrm{N}\left(\mu \mathrm{g} \mathrm{g}^{-1}\right)$ & $337(99)$ & $-266(100)$ & 0.023 \\
\hline Inorganic- $\mathrm{N}\left(\mu \mathrm{g} \mathrm{g}^{-1}\right)$ & $351(102)$ & $-250(100)$ & 0.022 \\
\hline Organic-N $\left(\mu \mathrm{g} \mathrm{g}^{-1}\right)$ & $-4(43)$ & $-81(34)$ & 0.055 \\
\hline $\mathrm{C}_{\text {mic }}\left(\mu \mathrm{gg}^{-1}\right)$ & $1120(2543)$ & $6212(6570)$ & 0.448 \\
\hline $\mathrm{N}_{\text {mic }}\left(\mu \mathrm{g} \mathrm{g}^{-1}\right)$ & $-787(377)$ & $1748(699)$ & 0.031 \\
\hline
\end{tabular}

Results are presented for paired $t$-tests between unharvested sites $(U)$ and unharvested sites with foliage addition (UFA). Bolded values indicate significance at $p<0.05$.

${ }^{\mathrm{a}}$ Data $\log$ transformed.

Table 5

Spearman rank correlation coefficients between $\mathrm{F}$ horizon inorganic $\left(\mathrm{NO}_{3}^{-}-\mathrm{N}\right.$ and $\left.\mathrm{NH}_{4}^{+}-\mathrm{N}\right)$ and organic-N accumulation during a 90 -day laboratory incubation and soil $\mathrm{N}$ and $\mathrm{C}$ concentrations, and $\mathrm{C}: \mathrm{N}$ ratio

\begin{tabular}{|c|c|c|c|c|c|c|}
\hline & \multicolumn{2}{|c|}{ Soil $\mathrm{N}\left(\mathrm{g} \mathrm{kg}^{-1}\right)$} & \multicolumn{2}{|c|}{ Soil $\mathrm{C}\left(\mathrm{g} \mathrm{kg}^{-1}\right)$} & \multicolumn{2}{|c|}{ Soil C:N } \\
\hline & $r$ & $p$ & $r$ & $p$ & $r$ & $p$ \\
\hline $\mathrm{NH}_{4}^{+}-\mathrm{N}\left(\mu \mathrm{g} \mathrm{g}^{-1} \mathrm{day}^{-1}\right)$ & -0.25 & 0.43 & 0.43 & 0.16 & 0.25 & 0.43 \\
\hline Inorganic-N $\left(\mu \mathrm{g} \mathrm{g}^{-1}\right.$ day $\left.^{-1}\right)$ & 0.85 & $<0.01$ & -0.65 & 0.02 & -0.85 & $<0.01$ \\
\hline Organic-N $\left(\mu \mathrm{gg}^{-1} \mathrm{day}^{-1}\right)$ & 0.33 & 0.30 & -0.50 & 0.10 & -0.33 & 0.30 \\
\hline
\end{tabular}

Bolded values indicate significance at $p<0.05$.

significant only for the $0-5 \mathrm{~cm}$ mineral soil. In a recent study in a 235-year-old black spruce stand in the southern boreal forest of Quebec (Lapointe et al., 2005) also showed a small, but not statistically significant increase in net nitrification in the $\mathrm{F}$ layer for the first 3 years after clearcutting. The "careful logging" practiced in the Quebec experiment maintained all tree crowns and branches on the harvested sites, in contrast to the full-tree harvesting at our sites, which re-located large amounts of logging slash to the roadside. Even though differences in slash loadings could have the potential to effect site $\mathrm{N}$ dynamics, winter harvesting at both sites prevented any major physical disturbance to the soil surface. Organic F horizons from the 2001 clearcuts were relatively undisturbed and the same depth as those in the uncut boreal stands. The net production of inorganic- $\mathrm{N}$ and the decline in $\mathrm{C}_{\mathrm{mic}}$ and $\mathrm{N}_{\text {mic }}$ in the $\mathrm{F}$ horizon of the recent clearcuts over the incubation period demonstrated that the immobilization observed in the foliage addition experiment did not occur to the same degree in these soils.

The incubation results for the recent clearcuts can lead to two possible scenarios with regard to the impact of logging slash on $\mathrm{N}$ dynamics in the field. One possibility is that the mineralization potential of our soils have shifted from a period of net $\mathrm{N}$ immobilization to net $\mathrm{N}$ mineralization two growing seasons after harvest. After two growing seasons on the ground in clearcuts at the ELRA, black spruce needle slash $\mathrm{C}$ content had declined $23 \%$, while $\mathrm{N}$ content had increased $15 \%$ in comparison to live current foliage from uncut stands. Studies with various litter types have shown that a two-phase model can represent litter decomposition in unharvested stands, with the greatest mass loss taking place during the first year after placement on the forest floor (Berg et al., 2001; Trofymow et al., 2002). Black spruce litter placed at 21 different sites in the Canadian Intersite Decomposition Experiment (CIDET) averaged a 1 and 3 year mass loss of $28 \%$ and $44 \%$, respectively (Preston et al., 2000). The rapid loss of easily degradable $\mathrm{C}$ from litter soon after deposition on the soil surface could indicate that any stimulation of microbial communities leading to $\mathrm{N}$ immobilization may happen during a short time period after forest harvesting. The second possibility is that $\mathrm{N}$ immobilization is not important in these soils after harvest. While we might anticipate that logging slash from harvesting would provide a labile $\mathrm{C}$ source, slash was generally layered on the surface of the litter or moss layer, well separated from the F horizon we sampled for our incubation studies. Studies reporting net immobilization after forest harvesting have been associated with more aggressive site preparation and assimilation of organic residues into the upper soil profile such as drum chopping in loblolly pine plantations (Vitousek and Matson, 1985) and soil mixing in a boreal mixedwood (Frey et al., 2003).

The incubation results for the 12-year-old clearcuts supported the hypothesis that modifications to substrate 

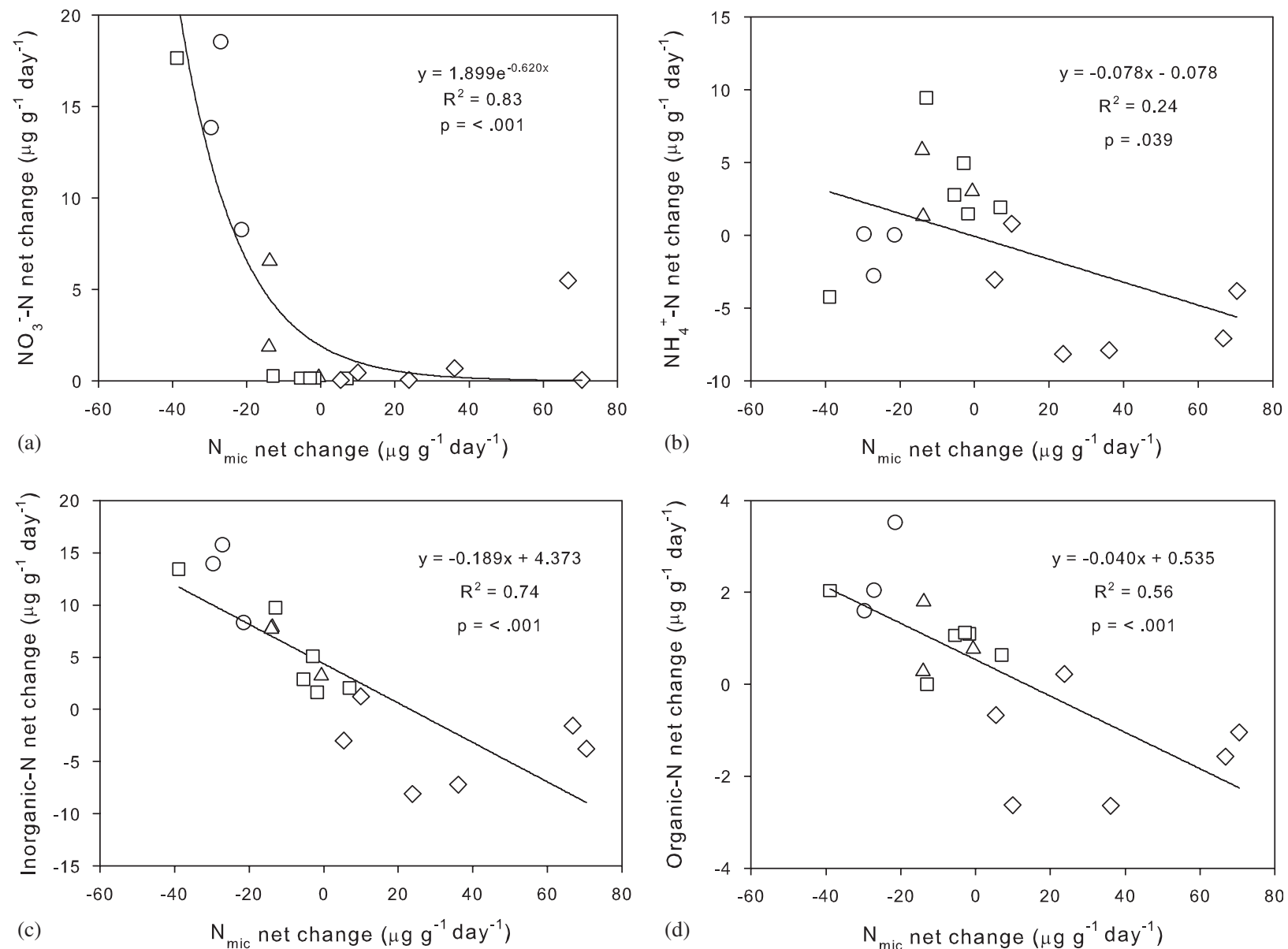

(d)

\begin{tabular}{|ll|}
\hline & Harvested 1991 \\
$\triangle$ & Harvested 2001 \\
$\square$ & Unharvested \\
$\diamond$ & Unharvested FA \\
\hline
\end{tabular}

Fig. 6. Relationships between microbial biomass $\mathrm{N}\left(\mathrm{N}_{\text {mic }}\right.$ ) and (a) $\mathrm{NO}_{3}^{-}-\mathrm{N}$ (b) $\mathrm{NH}_{4}^{+}-\mathrm{N}$ (c) inorganic- $\mathrm{N}$ and (d) organic- $\mathrm{N}$ during laboratory incubation of $\mathrm{F}$ horizon from the Esker Lakes Research Area. Values are expressed as daily net change over the entire incubation period representing 0-90 days incubation for harvested 1991, harvested 2001 and unharvested sites and 30-90 days incubation for the unharvested with foliage addition (FA) treatment.

quality as a result of full-tree harvesting influenced $\mathrm{N}$ dynamics in the boreal soils at the ELRA. The significant differences in $\mathrm{NO}_{3}^{-}-\mathrm{N}$ accumulation for $\mathrm{F}$ horizon and shallow mineral soil between 1991 clearcuts and unharvested stands demonstrated that the impacts of harvesting at these sites were evident at a point in time several years after forest removal. Conceptual models of nutrient availability in forest soils after disturbance (Kimmins, 2004) described the immediate post-harvest nutrient flush, or so-called assart effect, which resulted from the leaching of readily available nutrients from logging slash. For the boreal soils at the ELRA, under full-tree harvesting practices, our findings indicated that a nutrient flush due to increased $\mathrm{N}$ mineralization could occur several years after cutting and plantation establishment.

Our results differed from those of Bradley et al. (2002), who examined $\mathrm{N}$ dynamics in the forest floor layers for a post-clearcut chronosequence in stands of Pacific silver fir and western hemlock on Vancouver Island. They found that the highest $\mathrm{N}$ mineralization rates for in situ buried bag incubations and the highest $\mathrm{N}$ concentrations from ion exchanges resins were in 4-year-old clearcuts when compared to older clearcuts (7, 11 and 27 years old). Bradley et al. (2002) speculated that increasing root-C inputs with regenerating vegetation resulted in increased heterotropic immobilization and therefore decreased $\mathrm{N}$ mineralization at their older clearcut sites.

For the $\mathrm{F}$ horizons from 12-year-old clearcuts in our study the consistent declines in $\mathrm{C}_{\text {mic }}$ and $\mathrm{CO}_{2}-\mathrm{C}$ evolution rates indicated depletion in the supply of labile $\mathrm{C}$ during the incubation period. Litter input to these sites had been reduced compared to uncut stands since harvest. In addition to canopy removal through harvest and a slow recovery of litter input in planted spruce, the silvicultural practice of herbiciding to establish plantations had decreased $\mathrm{C}$ inputs to the forest soil. Harris and Riha (1991) reported lower $\mathrm{CO}_{2}$ evolution during laboratory incubations of forest floor materials that were collected in late summer and reasoned 
that this occurred because most of the labile $\mathrm{C}$ in litter was exhausted in the field prior to sampling. Results from the Ecosystem Management Emulating Natural Disturbance (EMEND) study on the boreal plain in Alberta demonstrated differences in the properties of organic matter of $\mathrm{FH}$ layers of spruce and aspen stands 4 years after full-tree winter harvesting (Hannam et al., 2005). Harvested forest floor layers were more enriched in aromatic $\mathrm{C}$ than unharvested layers and the aromatic $\mathrm{C}$ showed a shift to a greater abundance of $\mathrm{C}$-aryl $\mathrm{C}$, an indication of greater humification. The authors of this study reported that decreased litterfall and fine root turnover after harvest were possible explanations for the changes in forest floor chemical properties and that these changes could result in alterations in nutrient cycling. While we were not able to demonstrate statistically significant differences, the lower C concentrations and $\mathrm{C}: \mathrm{N}$ ratios of the $\mathrm{F}$ horizons sampled from the 1991 clearcuts compared to unharvested stands suggested a greater degree of humification for older clearcut $\mathrm{F}$ horizons in our study.

\subsection{Microbial biomass and N-availability in the F horizon}

Measurements of net $\mathrm{N}$ mineralization provide an assessment of internal $\mathrm{N}$ cycling in forest soils based on the concurrent microbial processes of production and immobilization. Microbial growth in soils depends in part on the availability of nutrients, and as a result, changes in microbial biomass levels can result in either an increase or decrease in N availability in soils (Myrold, 1999). Further, temporal changes in microbial biomass have been shown to be reduced with increased soil organic C (Wardle, 1998).

During our incubation the stability of the microbial biomass, defined as the resistance of soil microbial organisms to disturbance (Wardle, 1998) within the F horizon appeared to be diminished in 12-year-old clearcuts when compared to 2-year-old clearcuts and unharvested stands. The results of our incubation provided strong evidence that microbial biomass changes were influencing $\mathrm{N}$ availability in the $\mathrm{F}$ horizon of these boreal forest soils. While positive net changes in the concentrations of inorganic and organic- $\mathrm{N}$ during the 90-day period are most obvious in the old clearcuts, the gradient in $\mathrm{N}$ production for all $\mathrm{F}$ horizons used in our incubation experiment analyzed as a group was also related to changes in $\mathrm{N}_{\text {mic }}$. Although differences in substrate quality are caused most noticeably by forest harvesting they are also inherent properties of undisturbed sites that result in some variation in the net change of $\mathrm{N}_{\text {mic }}$ and net $\mathrm{N}$ mineralization. Bauhus et al. (1998) found that certain microbial variables were sensitive to tree species composition in the southern boreal forest of Quebec. Sites used in our study were black spruce dominated, but did have varying amounts of other over- and under-story species present that could modify litter inputs, incubation substrate quality and net $\mathrm{N}$ mineralization. With the addition of foliage to the $\mathrm{F}$ horizon we were able to stimulate microbial growth, increase $\mathrm{C}_{\text {mic }}$ and $\mathrm{N}_{\text {mic }}$, and as result produce a negative net change in $\mathrm{N}$ availability during the incubation period. Raubach and Joergensen (2002) examined $\mathrm{C}_{\text {mic }}, \mathrm{N}_{\text {mic }}$ and $\mathrm{N}$ mineralization rates as measured by the difference of $\mathrm{N}$ input and output from a $20 \mathrm{~cm}$ depth core in an unharvested coniferous forest soil in the field. They concluded that temporal variation in microbial biomass was unrelated to $\mathrm{N}$ mineralization, but that $\mathrm{N}$ mineralization was related to soil temperature. In their study, temperature was the experimental factor and microbial biomass $\mathrm{C}$ and $\mathrm{N}$ did not change over a 12-month period. Our approach of examining $\mathrm{N}$ mineralization along a broad continuum of net change in $\mathrm{N}_{\text {mic }}$ isolated the role of substrate quality and enabled the evaluation of significant changes in $\mathrm{N}_{\text {mic }}$ on net $\mathrm{N}$ mineralization.

\subsection{Study limitations}

Our laboratory incubations were executed at constant temperature and moisture and while not representative of the conditions in the field, more noteworthy is the fact that temperature and moisture would likely not be constant across the different treatments. Our experiments were intentionally designed to assess $\mathrm{N}$ mineralization under optimal conditions for microbial activity and as such represent a potential availability of $\mathrm{N}$ for leaching. Also of note is the fact that we have considered soil concentrations in our study. Incorporation of soil mass through estimates of bulk density would enable determination of contents of $\mathrm{N}$ produced per area within the forest soil. While our results showed increased nitrification in harvested soils at the ELRA, at this point in time we can only speculate with regard to the fate of the $\mathrm{NO}_{3}^{-}-\mathrm{N}$ produced. Growth of plantations and other non-commercial species in clearcuts provide a sink for $\mathrm{N}$, and as vegetation develops over time nutrient demand will increase. In terms of $\mathrm{N}$ loss from harvested areas and export to surface waters, greater vegetative demand as plantations age can temper the impact of increased net $\mathrm{N}$ mineralization. In addition, whether $\mathrm{NO}_{3}^{-}-\mathrm{N}$ will be exported to the aquatic system will depend on the existence and the type of hydrological pathway by which water moves through the terrestrial portion of the watershed. Biogeochemical processes occurring deeper in the soil profile and within riparian buffer zones such as vegetative uptake, denitrification and microbial immobilization could also be factors that result in a modification of $\mathrm{N}$ leached from the surface horizons of cutover soils.

Another consideration in our experiment is the fact that the exposed surface area of needles added to incubating $\mathrm{F}$ horizon was greater than would be encountered in clearcuts after harvest at the ELRA. This treatment could produce more dramatic $\mathrm{N}$ immobilization than actually occurs in the field. From an experimental point of view our decision to incorporate the needles in this way was to provide the best possible conditions to see if we could demonstrate $\mathrm{N}$ immobilization with soil and logging slash from our sites. Amending samples with oven-dried current foliage 
provided a standardized slash material that we were able to add in equal weights to each sample. Other possible issues with regard to the foliage addition experiment relate to the quantity and moisture content of the foliage added, the type of logging slash added (other tree components such as bark, branches and roots are also left on site after harvest) and the initial degree of decomposition of the foliage, as partially decomposed tree components including foliage are left on site and would have different chemical properties than the current live foliage we used. The variable nutrient and moisture content of logging slash in the field could result in different rates of microbial colonization and changes in the degree of decomposition compared to our laboratory incubation.

\section{Conclusions}

Our study has demonstrated a greater potential for $\mathrm{NO}_{3}^{-}-\mathrm{N}$ production in soils from 12-year-old clearcuts when compared to 2-year-old clearcuts and unharvested boreal forest stands. In addition, the variability in substrate between harvested and unharvested sites affected microbial biomass cycling that controlled $\mathrm{N}$ availability in the forest soil. This is a significant result in that $\mathrm{NO}_{3}^{-}-\mathrm{N}$ production in soils could produce impacts on surface water quality several more years after harvest than anticipated from previous studies where terrestrial production of $\mathrm{NO}_{3}^{-}-\mathrm{N}$ peaked in the first few years after logging (Gordon and Van Cleve, 1983; Simard et al., 2001; Bradley et al., 2002). The foliage addition experiment indicated that maintenance of logging slash on site has the potential to immobilize $\mathrm{N}$ and minimize the risk of off-site $\mathrm{N}$ losses; however, this effect appeared to be short-lived, as inorganic- $\mathrm{N}$ as $\mathrm{NO}_{3}^{-}-\mathrm{N}$ was available in the soils of recent clearcuts. Modifications of forest harvesting methods, to either increase logging slash by the use of stem-only harvesting, or decreasing logging slash by removal from site for manufacture of biofuels or other non-timber forest products could have an impact on $\mathrm{N}$ availability in the forest soil.

It is only by way of a thorough assessment of the biogeochemical and hydrological processes controlling the $\mathrm{N}$ cycle at this site that we can determine and understand the impact of harvesting on aquatic ecosystems. Additional studies at the ELRA have been established to assess the combined influence of logging slash, regenerating vegetation uptake and hydrologic pathways on $\mathrm{N}$ export to the aquatic system. We are estimating $\mathrm{N}$ leaching from the forest floor and mineral soil horizons using zero-tension and tension lysimeters, and piezometers at full-tree harvested sites and within forested buffers on the shorelines of boreal lakes to evaluate the risk of increased nutrient export to boreal lakes.

\section{Acknowledgements}

We gratefully acknowledge the field and laboratory assistance of Johanna Curry, Sharon Gibbs, Linda Irwin,
Ameur Manceur, Mark Jantunen, Susantha Jayasundara, Mike Johns, Tara Lannigan, Steve O'Brien, Nathan OwenGoing and Liisa Ukonmaanaho. We thank Dr. Robert Fleming and two anonymous reviewers for their constructive comments on the original manuscript. Financial support for this work was provided by the Sustainable Forest Management (SFM) Network and the Forest Ecosystem Processes Network of Natural Resources Canada-Canadian Forest Service.

\section{References}

Bååth, E., Lohm, U., Lundgren, B., Rosswall, T., Söderström, B., Solenius, B., Wiren, C., 1978. The effect of nitrogen and carbon supply on the development of soil organism populations and pine seedlings: a microcosm experiment. Oikos 31, 153-163.

Bauhus, J., Paré, D., Coté, L., 1998. Effects of tree species, stand age and soil type on soil microbial biomass and its activity in a southern boreal forest. Soil Biology and Biochemistry 30, 1077-1089.

Berg, B., McClaugherty, C., Virzo De Santo, A., Johnson, D., 2001. Humus buildup in boreal forests: effects of litterfall and its $\mathrm{N}$ concentration. Canadian Journal of Forest Research 31, 988-998.

Bradley, R.L., Kimmins, J.P., Martin, W.L., 2002. Post-clearcutting chronosequence in the B.C. Coastal western hemlock zone: II. Tracking the assart flush. Journal of Sustainable Forestry 14, 23-43.

Brais, S., Camiré, C., Bergeron, Y., Paré, D., 1995. Changes in nutrient availability and forest floor characteristics in relation to stand age and forest composition in the southern part of the boreal forest of northwestern Quebec. Forest Ecology and Management 76, 181-189.

Brais, S., Paré, D., Camiré, C., Rochon, P., Vasseur, C., 2002. Nitrogen net mineralization and dynamics following whole-tree harvesting and winter windrowing on clayey sites of northwestern Quebec. Forest Ecology and Management 157, 119-130.

Carignan, R., D'Arcy, P., Lamontagne, S., 2000. Comparative impacts of fire and forest harvesting on water quality in Boreal Shield lakes. Canadian Journal of Fisheries and Aquatic Sciences 57, 105-117.

Carmosini, N., Devito, K.J., Prepas, E.E., 2002. Gross nitrogen transformations in harvested and mature aspen-conifer mixed forest soils from the Boreal Plain. Soil Biology and Biochemistry 34, 1949-1951.

Carmosini, N., Devito, K.J., Prepas, E.E., 2003. Net nitrogen mineralization and nitrification in trembling aspen forest soils on the Boreal Plain. Canadian Journal of Forest Research 33, 2262-2268.

Chapman, L.J., Thomas, M.K., 1968. The climate of northern Ontario. Canadian Department of Transport Meteorological Branch, Climatological Studies 6, 58pp.

Environment Canada, 2004. National Climate Data and Information Archive. Available from 〈http://www.climate.Weatheroffice.ec.gc.ca/ climateData $>$.

Frey, B.R., Lieffers, V.J., Munson, A.D., Blenis, P.V., 2003. The influence of partial harvesting and forest floor disturbance on nutrient availability and understory vegetation in boreal mixedwoods. Canadian Journal of Forest Research 33, 1180-1188.

Gordon, A.M., Van Cleve, K., 1983. Seasonal patterns of nitrogen mineralization following harvesting in the white spruce forests of interior Alaska. In: Wein, R.W., Pierce, R.R., Methyen, I.R. (Eds.), Resources and Dynamics of the Boreal Zone. Association of Canadian Universities for Northern Studies, Sault Ste. Marie, ON, pp. 119-130.

Grenon, F., Bradley, R.L., Joanisse, G., Titus, B.D., Prescott, C.E., 2004. Mineral $\mathrm{N}$ availability for conifer growth following clearcutting: responsive versus non-responsive ecosystems. Forest Ecology and Management 188, 305-316.

Hannam, K.D., Quideau, S.A., Kishchuk, B.E., Oh, S.-W., Wasylishen, R.E., 2005. Forest-floor chemical properties are altered by clearcutting in boreal mixedwood forest stands dominated by trembling 
aspen and white spruce. Canadian Journal of Forest Research 35, 2457-2468.

Harris, M.M., Riha, S.J., 1991. Carbon and nitrogen dynamics in forest floor during short-term laboratory incubations. Soil Biology and Biochemistry 23, 1035-1041.

Hazlett, P.W., Gordon, A.M., Sibley, P.K., Buttle, J.M., 2005. Stand carbon stocks and soil carbon and nitrogen storage for riparian and upland forests of boreal lakes in northeastern Ontario. Forest Ecology and Management 219, 56-68.

Jones, R.K., Pierpoint, G., Wickware, G.M., Jeglum, J.K., Arnup, R.W., Bowles, J.M., 1983. Field Guide to Forest Ecosystem Classification for the Clay Belt. Ontario Ministry of Natural Resources, Queen's Printer for Ontario, 161pp.

Kimmins, J.P., 2004. Forest Ecology-A Foundation for Sustainable Management and Environmental Ethics in Forestry, third ed. Prentice Hall, Upper Saddle River, NJ, USA, 611pp.

Lamontagne, S., Carignan, R., D'Arcy, P., Prairie, Y.T., Paré, D., 2000. Element export in runoff from eastern Canadian Boreal Shield drainage basins following forest harvesting and wildfires. Canadian Journal of Fisheries and Aquatic Sciences 57, 118-128.

Lapointe, B., Bradley, R.L., Shipley, B., 2005. Mineral nitrogen and microbial dynamics in the forest floor of clearcut or partially harvested successional boreal forest stands. Plant and Soil 271, 27-37.

Myrold, D.D., 1999. Transformations of nitrogen. In: Sylvia, D.M., Fuhrmann, J.L., Hartel, P.G., Zuberer, D.A. (Eds.), Principles and Applications of Soil Microbiology. Prentice Hall, Upper Saddle River, NJ, USA, pp. 259-294.

Nicolson, J.A., Foster, N.W., Morrison, I.K., 1982. Forest harvesting effects on water quality and nutrient status in the boreal forest. In: Steed, G.L., Hudson, H.R. (Eds.), Canadian Hydrology Symposium '82. National Research Council of Canada, Ottawa, ON, pp. 71-89.

Paré, D., Bergeron, Y., 1996. Effect of colonizing tree species on soil nutrient availability in a clay soil of the boreal mixedwood. Canadian Journal of Forest Research 26, 1022-1031.

Pluth, D., Nommik, H., Wiklander, G., Larsson, K., Eriksson, A., 1995. Carbon and nitrogen mineralization of harvesting residues of Pinus sylvestris $L$. during aerobic laboratory incubation. Scandinavian Journal of Forest Research 10, 97-107.

Prepas, E.E., Pinel-Alloul, B., Planas, D., Methot, G., Paquet, S., Reedyk, S., 2001. Forest harvest impacts on water quality and aquatic biota on the Boreal Plain: introduction to the TROLS lake program. Canadian Journal of Fisheries and Aquatic Sciences 58, 421-436.

Preston, C.M., Trofymow, J.A., and the Canadian Intersite Decomposition Experiment Working Group, 2000. Variability in litter quality and its relationship to litter decay in Canadian Forests. Canadian Journal of Botany 78, 1269-1287.

Putz, G., Burke, J.M., Smith, D.W., Chanasyk, D.S., Prepas, E.E., Mapfumo, E., 2003. Modelling the effects of boreal forest landscape management upon streamflow and water quality: Basic concepts and considerations. Journal of Environmental Engineering and Science 2, S87-S101.

Raubach, M., Joergensen, R.G., 2002. C and net $\mathrm{N}$ mineralization in a coniferous forest soil: the contribution of the temporal variability of microbial biomass $\mathrm{C}$ and N. Soil Biology and Biochemistry 34, 841-849.

Rowe, J.S., 1972. Forest Regions of Canada. Department of Environment, Canadian Forestry Service, Publication 1300, Ottawa, ON, 172pp.

Schimel, J.S., Bennett, J., 2004. Nitrogen mineralization: challenges of a changing paradigm. Ecology 85, 591-602.

Simard, D.G., Fyles, J.W., Paré, D., Nguyen, T., 2001. Impacts of clearcut harvesting and wildfire on soil nutrient status in the Quebec boreal forest. Canadian Journal of Soil Science 81, 229-237.

Smith, C.K., Munson, A.D., Coyea, M.R., 1998. Nitrogen and phosphorus release from humus and mineral soil under black spruce in central Quebec. Soil Biology and Biochemistry 30, 1491-1500.

Smith, C.K., Coyea, M.R., Munson, A.D., 2000. Soil carbon, nitrogen and phosphorus stocks and dynamics under disturbed black spruce forests. Ecological Applications 10, 775-788.

Soil Classification Working Group, 1998. The Canadian System of Soil Classification, third ed. Agriculture and Agri-Food Canada, Publication 1646, Ottawa, Ont., Canada, 187pp.

Steedman, R.J., 2000. Effects of experimental clearcut logging on water quality in three small boreal forest lake trout (Salvelinus namaycush) lakes. Canadian Journal of Fisheries and Aquatic Sciences 57, 92-96.

Stottlemyer, R., Toczydlowski, D., 1999. Nitrogen mineralization in a mature boreal forest, Isle Royale, Michigan. Journal of Environmental Quality 28, 709-720.

Trofymow, J.A., Moore, T.R., Titus, B., Prescott, C., Morrison, I., Siltanen, M., Smith, S., Fyles, J., Wein, R., Camiré, C., Duschene, L., Kozak, L., Kranabetter, M., Visser, S., 2002. Rates of litter decomposition over 6 years in Canadian forests: influence of litter quality and climate. Canadian Journal of Forest Research 32, 789-804.

Vitousek, P.M., Matson, P.A., 1985. Disturbance, nitrogen availability, and nitrogen losses in an intensively managed loblolly pine plantation. Ecology 66, 1360-1376.

Voroney, R.P., Winter, J.P., Beyaert, R.P., 1993. Soil microbial biomass C and N. In: Carter, M.R. (Ed.), Soil Sampling and Methods of Analysis. Canadian Society of Soil Science. Lewis Publishers, Ottawa, Ont., Canada, pp. 277-286.

Walley, F.L., Van Kessel, C., Pennock, D.J., 1996. Landscape-scale variability of $\mathrm{N}$ mineralization in forest soils. Soil Biology and Biochemistry 28, 383-391.

Wardle, D.A., 1998. Controls of temporal variability of the soil microbial biomass: a global-scale synthesis. Soil Biology and Biochemistry 30, $1627-1637$ 